\title{
Sahne Tasarımının Gelişim Süreci İçerisinde Teknik ve Teknolojinin Önemi
}

\author{
The Importance of Technique and Technology in The Development Process of \\ The Stage Design \\ Yasin Karaçam \\ Yüksek Lisans Öğrencisi, Atatürk Üniversitesi, Güzel Sanatlar Enstitüsü, Sahne Sanatları Bölümü \\ email: yasin.karacam15@ogr.atauni.edu.tr (1) ORCID ID: https://orcid.org/0000-0003-2643-0001
}

\begin{abstract}
$\underset{\text { TorAuthors seseserchers }}{\text { iThenticate }}$ Bu makale bilimsel etik ve kurallara uygun hazırlanmış ve intihal incelemesinden geçirilmiştir. Etik kurul onayı gerektirmemektedir.

Atıf (APA 6)/To cite this article

Karaçam, Y. (2021). Sahne tasarımının gelişim süreci içerisinde teknik ve teknolojinin önemi. Atatürk Üniversitesi Güzel Sanatlar Enstitüsü Dergisi, 27(46), 201-220. https://doi.org/10.35247/ataunigsed.827838

Makale Gönderim Tarihi/Received: 18/11/2020

Makale Kabul Tarihi/Accepted: 27/02/2021

Makale Yayın Tarihi/Published: 30/03/2021

Review Article/Derleme Makale

$\ddot{O} z$

Geçmişten günümüze sahne tasarımında kullanılan araçlar, teknikler, üsluplar ve yenilikler, içinde bulunduğu çağın sosyalekonomik-kültürel ve teknolojik ilerlemeleriyle paralel bir gelişim ve değişim göstermiştir. Bu çalışmada; günümüze kadar süre gelen tiyatro sanatında önemli bir yere sahip olan, sahne tasarımı alanında çağlar boyu gerçekleşmiş teknik yenilikler ve gelişmelerin, dönemler bağlamında incelenmesi, teknik ve teknolojik yeniliklerin sahne tasarımına yansımaları ve katkılarının araştırılması amaçlanmıştır. Çalışmada nitel araștırma yöntemi kullanılarak tarihsel süreç içinde sahne tasarımı alanında yaşanan teknik ve teknolojik gelişmeler verilerin

Abstract

Tools, techniques, styles, and innovations used in stage design from past to present have developed and changed in parallel with the social, economic, cultural, and technological advances of the era. This study aims to analyze the technical innovations and developments in the field of stage design, which has an important place in the art of theater that has survived until today, and the reflections and contributions of technical and technological innovations to stage design in the context of periods. In the research, technical and technological developments in the field of stage design in the historical process were realized by collecting and analyzing data using the qualitative research method.
\end{abstract} toplanıp incelenmesiyle gerçekleştirilmiștir.

Anahtar kelimeler: Sahne Tasarımı, Tiyatro, Teknoloji, Teknik
Keywords: Stage Design, Theatre, Technology, Technique

\section{Giriş}

Sahne tasarımı kavramı, günümüz kullanımı açısından on dokuzuncu yy. sonu ve yirminci yy. başında kullanılmaya başlanmıştır. Modern çağla birlikte teknik ve teknolojik gelişimlerden etkin bir biçimde yararlanan sahne tasarımı, tiyatro sanatında oyuncu ve yazar kadar önemli bir konum teşkil etmektedir. Günümüz teknolojik gelişimleri, tüketim toplumunun teknolojiye olan bağımlılığı tiyatro sanatını her dönemde olduğu gibi modern dönemde de teknik ve teknolojik yenilikler ile özellikle sahne tasarımı alanında etkilemiş ve gelişmesine etken bir araç olmuştur. Gelişen teknolojik yenilikler birey üzerindeki zaman-mekân algısını değiştirmiştir. Değişen birey algısıyla birlikte tiyatro sanatında etken olan yanılsama yaratımı geneli itibariyle sahne tasarımı alanında teknik ve teknolojik gelişmelerden yararlanılarak yapılır olmuştur. Yanılsama yaratımında ve sahne tasarımı konusunda mekân (tiyatro sahnesi) önemli bir yer teşkil etmektedir.

Sahne tasarımı için gerekli olan mekân antik Yunan döneminde ilk kez toplantılar çeşitli tartışmalar ve tiyatro oyunlarında gösterim sağlamak amacı ile yapılmıştır. Şu anda varlığını sürdüren amfi tiyatrolar ilk kez antik Yunan döneminde kullanıma sunulmuştur (Aksel, 1988). Açık alanlardan yarı kapalı yapılara geçiş yapan tiyatro sanatında teknik ve çağının getirmiş olduğu yenilikler Amfi tiyatrolarla birlikte kullanılmaya başlanmıştır. Antik Yunan medeniyetinde tiyatronun bulunduğu konum inançsal bir temel üzerinde yükselmekteydi. Bulunduğu konum gereği toplumsal yapının şekillendirilmesinde ve yönlendirilmesinde etken bir araç olarak kullanılıyordu. Seyircilerin inançlarının azalması durumlarından ya da oyundaki hikâyenin tıkanması durumunda teknik olanaklardan yararlanıp bir vinç yardımıyla sahneye makineden tanrı "deus ex machina" adında içinde oyuncu bulunan makineler sahne üzerine indiriliyordu (Yorgun, 2018, s. 55). Kullanılan makineler ve sistemler çağının içinde bulunduğu dönem gereği teknolojik olarak nitelendirilebilir. Çağlar boyu sahne tasarımı eylemi Antik Yunan tiyatrosunda olduğu gibi teknik ve teknolojik buluş ve gelişimlerden yoğun bir biçimde etkilenmiştir. İlerleyen dönemlerde özellikle Roma tiyatrosunda,

Antik anlatımlarda karmaşık makinelerden seyrek olarak söz açılmasına rağmen, Romalılar sahne tasarımında mekanik mucizelerin üstesinden gelmeyi biliyorlardı. Bu mekanizmanın İ.S. birinci yüzyılda amfı tiyatrolarda, özellikle Colosseum'da hayvanları yeraltı mekânlarından arena düzeyine kaldırmak için 
geliştirilmiş olduğu anlaşılmaktadır. Çok geçmeden bu mekanizma sahne dekoru amaçları için kullanılır olmaya başladı ve sahnenin yanında dekor parçalarını ve aksesuarları koymak için bir yapı kuruldu. Bu sahne donatımı gerektiğinde arenanın altına altı metre kadar uzatılan Colosseum'un mahzenine taşınırdı (Brockett, 2000, s. 76).

Orta Çă̆’ın karanlık ve yasaklayıcı yapısında tiyatro dini oyunları "misterium” anlatmak için bir araç olarak kullanılmıștır. Dini oyunlar kilisenin içinde ve eş zamanlı simultane sahnelerde oynanırken Antik Yunanda kullanılan makara ve vinç sistemlerini geliştirilmiş versiyonlarından yararlanılmıştır. Din dışı oyunlarsa gezici arabalarda şehir şehir gezerek sergilenmiştir. Orta çağda kullanılan yaygın araçların başında efektler gelmekteydi.

Rönesans ile makine kullanımda büyük ölçüde artış görülmüştür. Bu makine ve sistemlerin büyük bölümü uçma ile ilgiliydi. Kapalı mekanlara taşınana tiyatro gösterilerinde illüzyon etkisini yaratmak için makineler yardımıyla bu efektler yapılmaktaydı. Kapalı mekânlarda yapılmaya başlayan gösterilerde 1şıkta önemli bir konuma gelmişti yağ lambaları ve büyük mumlarla yapılan aydınlatma işlemi ışı teknolojilerinin gelişimiyle daha güvenilir daha kompleks özelliklere sahip makineler tarafından yapılır hale geldi.

İlerleyen dönemlerde sanayi devimiyle birlikte hızla gelişen teknolojik buluşlar tiyatro sanatı özelinde dekor tasarımında kullanılan teknik ve teknolojik makinelerin hızlı bir biçimde gelişmesine sebep olmuştur. Wagner'in toplu sanat kuramı "Gesamtkunstwerk" (ortak sanat yapıtı) kavramını gerçekçi bulamayan Adolpe Appia "sahne sunumunun çatışan üç öğeyi içerdiği sonucuna vardı: Devinen üç boyutlu oyuncu, düşey tasarım ve ufuksal zemin" (Brockett, 2000, s. 508) düşüncesinden yola çıkarak 1şı̆̆ın ve 1şık sayesinde oluşturulan gölgelerin önemi üzerinde duruyordu. Her ne kadar Wagner'in "Gesamtkunstwerk" kavramını gerçekçi bulmayarak onu eleştirmiş olsa da döneminde yapmış olduğu ışıkla atmosfer yaratma çalışmaları ve "Gesamtkunstwerk" düşüncesindeki çatışan ögelerin tespiti ve Wagner'in çalışmaları Appia'yı etkilemiştir. Appia Wagner'in çalışmaları da dahil olmak üzere Wagner'in fikirlerinin doğru yansıtılmadığını düşünerek üç farklı kuramsal kaynak hazırladı. Realizm akımıyla birlikte gelişen sahne tasarımında günümüzde yapılan sahne tasarımlarının öncül örnekleri oluşmaya başlamıştır.

Erwin Piscator teknik-teknoloji ve sanatı kendine has bir üslupla harmanlamayı başarmıştır. Projeksiyon teknolojisini etkin bir biçimde kullanan öncü tiyatro düşünürlerinden olmuştur. Politik tiyatro düşüncesinde yaratımda bulunduğu oyunlarda anlatımı kolaylaştırmak için teknolojik makinelerden etkin bir biçimde yararlanmıştır.

Realizm akımına tepkilerle ortaya çıkan, avangard akımlarla mitsel kökenlere dönüş yapılmış dekorda simgesel yapı olarak özetleyeceğimiz tasarımlar oluşturulmuştur. Rus avangardları özelinde Vsevolod Meyerhold düşünceleri ve sahne tasarımlarındaki değişimler günümüz çağdaş sahne tasarımını etkilemiştir. Bauhaus okulu Rus avangartlardan aldığı düşünce yapısını geliştirmiş kendi içerisinde çeşitli disiplinlerde eğitimler vererek sanatın toplumsal uzaklaşmasını önleme çabaları içerisinde bulunmuşlardır.

Günümüzde disiplinler arası alışverişin artışı teknik ve teknolojik gelişmeler bütün dönemlerde olduğu gibi günümüzde de sahne tasarımını etkilemiştir. Işsk, optik ve bilgisayar teknolojilerinin gelişimi ve bu gelişimden doğan teknolojinin maddi olarak ulaşılabilir hale gelişi deneysel tiyatro arayışlarında teknolojik unsurları kullanılabilir kılmıştır.

Antik çağlardan günümüze değin kullanılmış olan teknik ve teknolojik gelişmelerin sahne tasarımına yansımaları gözlenmiştir. Tarihsel süreç içerisinde kullanılan teknik teknolojik unsurların sahne tasarımına yansımaları, günümüz sahne tasarımına yön verip katkı sağlamış tiyatro kişilerine Richard Wagner'den, Adolphe Appia'ya, Edward Gordon Craig ve Erwin Piscator'dan, Walter Gropius özelinde Bauhaus okulu sahne tasarımcılarına, Vsevolod Meyerhold özelinde tarihsel Rus avangard sahne tasarımcılarına, tiyatro çalışmalarında teknolojiyi kullanan The Wooster Group, Robert Lapace, Robert Wilson gibi isimlere çalışmamızda değinilmiştir. Teknolojik olarak tiyatroda yeni ufuklar açabilecek sanal gerçeklik ve artırılmış gerçeklik teknolojilerine çalışmamızda değinilerek yer verilmiştir.

\section{Yöntem}

Araştırma Betimsel modele dayalı nitel bir araştırma olarak yürütülmüştür. Modele dayalı olarak literatür taraması yapılmış ve tarihsel süreç içinde sahne tasarımı alanında yaşanan teknik ve teknolojik gelişmeler verilerin toplanıp incelenmesiyle gerçekleştirilmiştir.

\section{Sahne Tasarımının Teknik ve Teknolojik Gelişimi}

"Antik Yunan tiyatrosunda dekor tasarımlarıyla ilgili yeterince kaynak olmamakla birlikte, az sayıda da olsa kaynaklar, sahne gereçleri, makineler ve dekorun kullanıldığını gösterir” (Nutku, 1985, s. 63). Antik Yunan tiyatrosunda amfi tiyatroların yapılmasıyla birlikte teknik gelişim ve yanılsama etkisini artırmak için çeşitli mekanik düzeneğin kullanıldığı bilinmektedir. 
Antik Yunan tiyatrosunda Vitruvius'un MÖ 14. yüzyılda mimarlık üzerine yazmış olduğu "De architectura" eserinde Yunan tiyatrosunda kullanılmış olan sahne tasarımı alanındaki teknik gelişmeleri görmekteyiz. "Periaktos" adı verilen bu yapı tiyatro sahnesini sergilemek ve hızlı bir biçimde değiştirmek amacıyla yapılmış olan dönen bir platform üzerine üçgen prizmalar yerleştirilmiş bir sistemdir. Nicola Sabbatini gibi çağının önde gelen sahne tasarımcıları da Rönesans tiyatrosunda bu teknikle sahne tasarımları yapmışlardır. Üçgen prizma yerine kare prizmanın da kullanılmış olduğu bilenmektedir. Fakat en iyi sonuç üçgen prizmalar sayesinde alınmıştır.

Vitrivius, Periaktoy üzerine neyin boyandığını da şöyle açıklar: "Biri trajik, ikincisi komik, üçüncüsü satir oyunları için olmak üzere, üç tür sahne vardır. Bezemeleri farklıdır ve tasarım olarak da birbirlerine benzemezler. Trajik sahneler krallara yaraşan sütunlar, alınlıklar, küçük heykellerle resmedilmiştir; komik sahneler, pencere ve balkonlarıyla özel konutları sergiler; satir sahneleri ise, ağaçlar, mağaralar, dağlar ve diğer kırsal öğeleri içeren kır manzarası biçiminde bezenmiştir (Brockett, 2000, s. 76).

Antik Yunan tiyatrosunda “Auleum” adı verilen sahne önü perdelerinin kullanılmış olduğu bilinmektedir. İ.Ö. 56 yılında kullanılan bu teknikte,

Sahnenin önündeki bir yivin içine birbiri içine geçen bir dizi sırık düzeniyle indirilmişti. Sırıkların yukarı doğru tüm yüksekliğini bulmasıyla perde kaldırılıyor, aksi işlem ile de indiriliyordu. İ. S. ikinci yüzyıldan sonra perde tepeden asılıyor ve iplerle kaldırılıyordu. Ön perde gösteri için önemliydi, çünkü bir sahnenin aniden meydana çıkmasına fırsat veriyo, ya da çarpıcı bir tabloyu çabuklukla gizlemeye yarıyordu. Ön perdenin sunulmasından önce karakterlerin hepsinin sahneye giriş ve çıkışları seyircinin gözü önünde yapilırdı (Brockett, 2000, s. 76).

\section{Görsel 1}

Periaktio Kullanımı, Yay Biçimli Pervazlar ve Özel Efektler İçin Arka Çukur (Joseph Fuittcnbach, Die Thealer Wcins (CI 899))

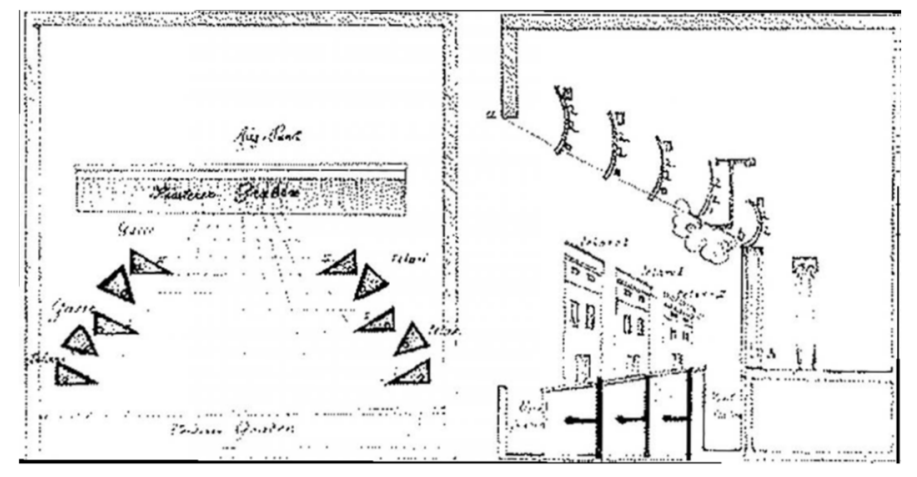

(Brockett, 2000).

Roma dönemi tiyatro yapılarında ise daha karmaşık ve teknik olarak geliştirilmiş makinelerden sıklıkla söz ediliyor. Fakat kullanılan yöntem ve tekniklerin Antik Yunan tiyatrosunda daha basit şekillerde kullanılmış olması muhtemeldir. Roma dönemi halkı sosyal yapısı gereği gösteri ağırlıklı eğlenceye yönelik ve içinde şiddet unsurları barındıran gösterileri izlemeyi sevmektedirler. Bu gibi gösterileri yapmak için özel sistemler üretilmiştir. "Çiçero 'ya göre, İ.Ö. 52 yılında Pompey Tiyatrosu'ndaki adanma gösterimlerinde, bir oyunda 600 katır sahneden geçmiş, bir başkasında 3.000 kâse sergilenmişti” (aktaran Brockett, 2000, s. 76). Bu tip gösterilerin artması özelliklede efektler konusunda Roma tiyatrosunun gelişim göstermesini sağlamıştır. Roma dönemi tiyatro yapılarında dekor olarak kullanılan asal unsur tiyatro yapısının kendisi olmuştur. Roma tiyatrosunda Geneli itibariyle makara sistemleri, tekerlekli dekor unsurları, efekt yapmakta kullanılan teknikler geliştirilip kullanılmıştır.

“Roma İmparatorluğu'nun Theodosius döneminde Hristiyanlığı resmi din olarak İ.S. 381 yılında kabul edilmesiyle" (Bulut, 2018) Roma dönemi tiyatrolarının özellikle din dışı oyunlarda işledikleri konuların dönemin dini yapısını rahatsız etmiştir. Bunun sonunda kaçınılmaz olarak yasaklarla karşılaşılmıştır. Yaklaşık İ.S. 5. ve 14. yy. arasında geçen Orta Çağ olarak bilinen bu dönemde tiyatro sanatı kilisenin egemenliği altına alınmıştır. Rahipler İncil'den bölümleri canlandırarak kilise önü ve içinde çeşitli olayları canlandırmışlardır. Dekor olarak geneli itibariyle kilisenin kendi iç yapısından yararlanılan Orta Çağ tiyatrosunda efektler büyük bir öneme sahiptir. Makara sistemlerinin ağırlıklı olarak kullanıldığı bu yapılarda "Bir oyunda, İsa'nın göğe yükselme sahnesinde, İsa rolünü oynayan oyuncu yukarıya makaralar ve halatlarla çekilmiş ve bulutların içinde kaybolduğu duygusunu vererek tanrı ve meleklerin yanına Cennete çıkarılmıştı. Cennet ise kilise tabanından 15 metre yüksekliğindeki bir platformla simgelenmişti” (Brockett, 2000, s. 105). 
Kiliseden ayrı, toplumun halk diliyle oynanan oyunlarda sahne sabit hareketsiz ya da taşınabilir sahneler şeklinde düzenekler ile gösterimler yapılması sağlanıyordu. Genel itibariyle "Corpus Christi” geçit alaylarında ise "Pageant" adı verilen arabalarla şehir şehir gezilerek gösterimler yapılmaktaydı. Orta Çağ tiyatrosunun genelinde gerçeklik duygusunu yaratmak için özel görsel efektler kullanılıyordu. "On beşinci ve on altıncı yüzyılda bunların sayısı çoğaldı ve karmaşıklaştı. Bu makineleri kullananların ustalıkları geliştikçe olağanüstü olayların gösterilmesi de çoğaldı" (Brockett, 2000, s. 105). Kullanılan bu efekt ve makinelerin çoğu "uçma" ile ilgiliydi. Çatılara kurulan bu makara sistemleri sayesinde bu efektler gerçekleştiriliyordu. Melek ve şeytanların makineler sayesinde gökten indikleri gösterilir ateş saçan canavarların tasvirleri sahne üstünde uçurularak canlandırılırdı.

Rönesans'la birlikte sahne tasarımında boyalı panolarda yanılsama etkisini arttıracak perspektifli resimler yapılmaya başlandı. Rönesans'ta tiyatro yapıları formal mekanlar olarak tasarlanmaya başlanırken, Sabastiano Serlio'nun (1475-1554) sahne tasarımları öncül bir önem teşkil etmekteydi. Serlio "Architettura" adlı eserinde trajik, komik ve satirik sahnelerin nasıl olması gerektiğini gösteren çizimlere yer verdi. "Modern sahnenin ilk örneği olarak genellikle Parma'daki Tcatro Farnese kabul edilir (Giovan Battista Aleotti tarafından tasarlanmış, 1618' de tamamlanmış ve ilk kez 1628' de kullanılmış) çünkü bu, ilk kalıcı çerçeve sahnesi olan ve günümüze kadar kalan tiyatro yapısıdır" (Brockett, 2000, s. 153). Rönesans'ta efektler de önemli bir unsurdu "Gök gürlemesi pürüzlü, inişli yokuşlu bir kanal boyunca yuvarlanan gülleler veya taşlarla yaratılıyor; rüzgâr ince kesilmiş, tahta şeritlerin havada hızla döndürülmesiyle yansılanıyordu (Brockett, 2000, s. 157). Rönesans'la birlikte kapalı formal yapılarda yapılmaya başlayan tiyatro sanatında 1şık kullanımında büyük gelişimler gözlendi.

17 yy. ilk yıllarında bütün dekor değişimlerinde aynı anda değiştirebilecek sistemlerin gelişimi üç farklı alanda bütünlük sağladı. "Sahne (arka arkaya dizilen tek kanatlı düz panolar, ç.n.), arka panolar (iki adet tek kanatlı düz panodan meydana gelen arka fon, ç.n.) ve üst pervazlar” (Brockett, 2000, s. 149). Değişimlerin sağlanabilmesi için makara ve halat sistemleri kullanılıyordu fakat bu yöntemle birçok kişinin koordineli olarak sistemi düzgün bir biçimde işletebilmeleri mümkün değildi. İnsanlar tarafından eş zamanlı olarak değişim sağlanamıyordu. Yine aynı dönemde direkli araba yöntemini geliştiren Giacomo Torelli (1608-1678) olmuştur. Sahne zemini boyunca uzun yarıklar açılmış, açılan bu yarıklardan paravanlara destek olması için direkler geçirilmiştir. Zeminin üzerinde direkler paravanlara dayandırılmıştır. Sahne altında, sahnenin önüne paralel olarak raylar eklenmiştir. Bu raylar üzerine arabalar bağlanmıştır ve bu arabalar hareket ediyorlardı. Arabalar sahne ortasına doğru gelince bağlı olduğu paravanlar görünür hale geliyordu. Arabaların sahne gerisine doğru gitmesiyle de paravanlar görüntüden çıkarılıyordu. Makara ve halatlardan oluşan bu sistemde dekorun her bir parçası tek bir vince bağlanılıyordu (A $=$ arabaların ürerinde gittiği raylar; $\mathrm{B}$ ve $\mathrm{C}=$ arabalar; $\mathrm{D}=$ sahne duvarları; $\mathrm{E}=$ sahne zemini; $\mathrm{F}, \mathrm{G}, \mathrm{H}$ ve $\mathrm{I}=$ sistemi işleten halatlar, makaralar ve manivelalar). Böylece bütün dekor unsurlarının eş zamanlı bir şekilde değiştirilmesi mümkün hale geliyordu. Gelişen bu teknikle bütün Avrupa tiyatrolarında 19. yy.'a kadar kullanılan bir sistem haline gelmiştir (Brockett, 2000, s. 150).

\section{Görsel 2}

Direkli Arabayla (Chariot-And-Pole) Değiştirme Mekanizmasının Şeması (Rees, Cyclopedia 20, 1803)

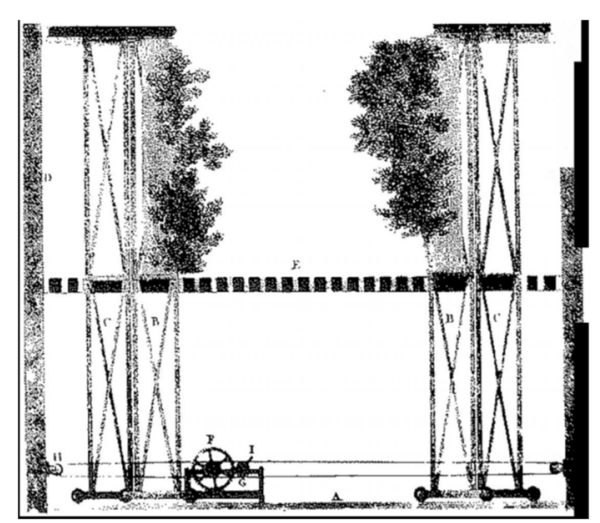

(Brockett, 2000).

Henry Irving 1881 yılında Lyceum'daki yapıtlarında 200 yılı aşkın bir süredir Avrupa tiyatrolarında yoğun bir biçimde kullanılan dekor değişimlerinde raylar "grooves" sayesinde sağlanan değişim yöntemini bıraktı. Raylar yerine serbest dekor "free plantation" değişimi yöntemini kullanan Irving, bu yöntemle istediği zamanlarda dekor değişimini yapmasını sağlamıştı. Bu yöntem sayesinde Irving dekor değişimlerinde tam bir serbestlik elde etmiştir. Irving, eski yöntemlerin birçoğunun kullanımını rafa kaldırmıştır. Dekor değişimleri için sahne perdelerinden yararlanan ilk İngiliz yapımcı olmuştur. 19. yy. başında sahne ekipmanlarında ağır kütleli unsurların kullanımı artmıştır. Bu unsurlar sahne üzerinde kurulu geniş asansörlerle değişimleri sağlanıyordu. Günümüzde de kullanılan bu yöntemde sahne yatayda alanlara bölünüyor ve her alan perdeyle kapatılıyordu. Zamanı gelince kalkan perdenin arkasında o sahnenin dekoru görülür hale geliyordu (Brockett, 2000, s. 463). 
19. yy.’da kullanılan bir diğer yeni yöntemse panorama tekniğiydi, bu yöntemde üstüne ç̧eşitli görseller çizilmiş kumaşlar iki silindir boru arasına yerleştiriliyordu. Döner silindirler borular sayesinde üstünde çeşitli görseller çizili olan bezlerle döngüsel hareket sağlanıyordu. Şu an günümüzdeki reklam panolarında kullanılan yönteme yakın bu teknikle hareketli görüntü gerektiren anlatımlar gerçekleştirilmiştir. İlk başta insan eliyle hareketlendirilen bu yöntem teknolojinin gelişmesiyle motorlardan yararlanılarak yapılmaya başlanmıştır. Panorama tekniği ile hareket gerektiren sahnelerin canlandırımı veya illüzyon etkisi sağlanıyordu. Yüksek bir dağa tırmanan birinin dağa tırmanma hissini oluşturmak için sahne yukarısından perdeye çizilmiş olan dağ görüntüsü oyuncunun hızıyla doğru orantılı olarak aşağı salınıyordu bu da sanki oyuncunun dağa tırmanıyormuş etkisini arttırmaktaydı. Brockett bu düzeneği şöyle aktarıyor; "Ben Hur'deki araba yarışı sahnesi gibi sahneler yaratmak için, hareketli perdeler bağlanmıştı. "Oyunda perdenin üstüne bir stadyum resmi boyanmıştı ve dörtnala koşan atların arkasında hareket ettiriliyordu. Perde değirmene bağlıydı. Değirmenin hızı yeni geliştirilmiş elektrikli motorlarla ayarlanıyordu" (Brockett, 2000, s. 465).

\section{Görsel 3}

Hareketli Panorama ve Ayak Değirmeni Kullanılarak Gerçekleştirilen Bir At Yarlşı (Georges Moynet, La Machinerie Theatrele, 1893).

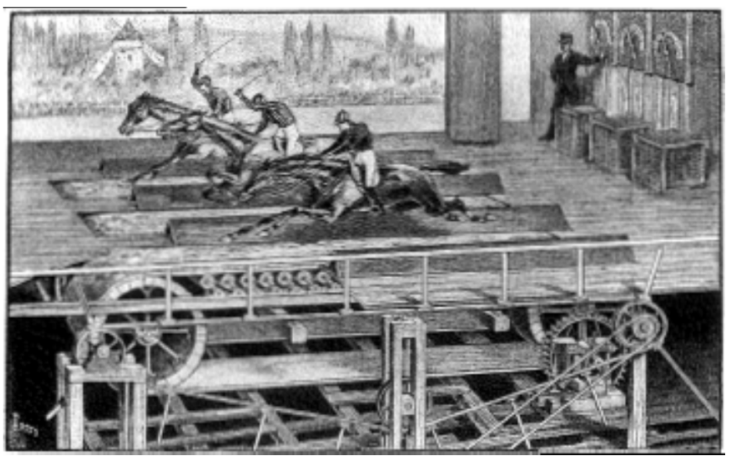

(Brockett, 2000).

19. yüzyılın ortalarından sonra 1862 yılına gelindiğinde Charles Dickens "Haunted Man” adlı oyununda John Henry Pepper "Pepper's Ghost” yöntemini kullanmıştır. Pepper's Ghost yöntemi eski bir sihirbazlık numarasının sahneye uygulanmış haliydi. Yanılsama etkisinin yoğun bir biçimde seyirciye iletildiği bu teknikle sahnede olmayan bir figürün sanki sahnedeymiş gibi görsel etkisi yaratılıyordu. Yöntem şu şekilde kullanılıyordu; sahne önü seyircinin görmeyeceği şekilde kapatılıyordu, seyircinin görmediği alanda gösterimi sağlanmak istenen obje veya oyuncunun üzerine 1şı yansıtılarak, 1şı yansıtılmış figürün yansıması açı1ı duran bir aynaya iletiliyordu ilk denemelerde aynadan yansıyan görüntü kumaş yüzeyine düşürülüyordu. Sonra daha iyi bir etki alındığg için yansıma cam yüzeyde yapılmıştır. Pepper's Ghost yöntemi günümüzde de kullanımı sürmekte olan bir yöntemdir. Temelde Pepper's Ghost yöntemi hologram yaratımının da temeli olarak düşünülebilir. Günümüzde kullanılan hologram yöntemindeyse belirli bir figüre 1şık yansıtmak gerekmemektedir. Projeksiyon cihazı kullanılarak yapılan günümüz Pepper's Ghost tekniğinde şu şekilde işlemektedir. Yine sahne önüne 45 derecelik açıyla duran parlaklık etkisi olan cam veya folyo ile bir ekran oluşturulmaktadır. Bu ekrana sahne üstünden projeksiyonla hareketli veya sabit görüntüler yansıtılmaktadır. Sahne önünde tabanda seyirciden gizlenmiş bir şekilde duran ikinci bir yansıtıcı (ayna) durmaktadır. Projeksiyondan aynaya yansıtılan görüntü sahne önünde 45 derecelik açıyla duran ikinci saydam yansitıcıya iletilmektedir. Saydam yansıtıcı sayesinde görüntünün yanılsaması seyirciye iletilmektedir. Bu yöntemle 2011 yılında Coachella Valley Müzik ve Sanat Festivali Snopp Dogg ile hayatını 1996 yılında kayıp eden şarkıcı Tupac’ın video görüntüsü kullanılarak konser gerçekleştirilmiştir (Öymen, 2007, s. 8).

\section{Görsel 4}

Pepper's Ghost Yönteminin Geçmişve Günümüz Konserinde Kullanım Şekli
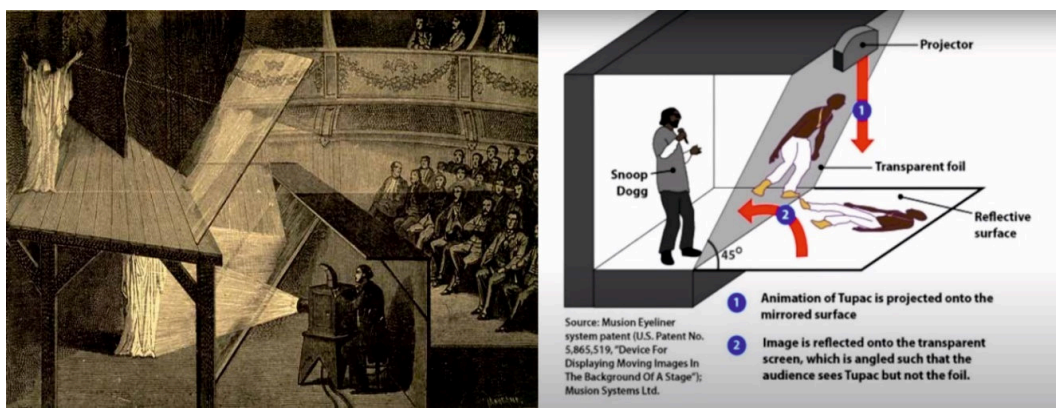

(iC3DsFX ve Plufke, t.y.). 
Sanayi devriminin de etkisiyle gelişim gösteren sahne tekniğinde kullanılan mekanik makineler, manuel (insan gücü) olarak çalıştırılıyorken, 19. yüzyılda elektriğin de bulunmasıyla otomatik (makine) sisteme geçiş açık bir biçimde görülmektedir. Mekanik alandaki gelişimlerin yanı sıra aydınlatma sistemlerinde de büyük gelişimler ve değişimlerden söz edilebilir. Tiyatro sanatının açık alanlardan kapalı alanlara (sahnelere) geçmesiyle birlikte aydınlatma ihtiyacı oluşmuştur. 16. yy. başı ve 18. yüzyıl sonu arasında elektrik teknolojisinin kullanılmasından önceki dönemleri kapsayan tarihlerde genellikle büyük mumlar, yağ lambaları ve gaz lambaları kullanılıyordu. Gelișen teknolojiyle birlikte reflektörler, mercekler ve ampulün bulunmasıyla da günümüzde kullanılan aydınlatma sistemlerinin gelişimi hızlı bir ivme kazanmıştır. Adolphe Appia (1862-1928), günümüz 1şık tasarımının gelişmesinde büyük katkısı olan önemli bir tiyatro düşünürüdür. Appia Wagner'in tiyatro düşüncelerini geliştirerek kendi sanat görüşünü oluşturuyordu. Wagner'in temelde yapmak istediği şey bütüncül bir tiyatro yapısını elde edebilmekti. Richard Wagner (1813-1883) yapmış olduğu çalışmalarıyla 20. yy. sahne düzeni ve denetimini köklü bir şekilde değiştiren isimlerden olmuştur. Ayrıca düşünceleriyle modern anlamdaki yönetmenlik kavramının da oluşmasında etken olmuştur. "Sanatçı, dram sanatını bütün sanatlar arasında en üstün konumda görür. Buna neden olarak dramın aklın engelini aşıp, duyular aracılığıyla algılayanın yüreğine işleme yetisine işaret eder" (Candan, 2003, s. 5). Wagner aynı zamanda sahne dekoru konusunda durağan boyalı panolar yerine hareketli ve devinim içiresinde bulunan bir sahne dekoru istemekteydi. Wagner'in çalışmaları birçok çağdaşını etkisi altına aldığı bilinmektedir. Wagner tiyatro mimarisinin seyirci ve yapıt arasında büyük bir önem teşkil ettiğini düşünmekteydi. "Bu fikir nedeniyle Wagner sahnede yanılsama etkisini artıracak fikirleri geliştiriyordu. Düşsel olan oyun dünyasıyla gerçek olan seyirci dünyasını keskin bir çizgiyle ayırmayı planlıyordu" (Candan, 2003, s. 7). Bunu yapabilmek için o tarihe kadar sahnede uygulanmamış seyir yerinin karartılması, perdenin alttan üstte doğru açılan bir hareketle değilde ortadan iki yana doğru açılmasını sağladı. Temeldeki sebepse sahnedeki yanılsama etkisini artırıp seyirciyi oyunun iç dünyasına girmesini sağlamaktı. Seyircinin tam bir dikkatle oyuna kendini vermesini istiyordu. Wagner ve SaxeMeiningen Dükü, II.Georg (1826-1914) ortak zamanlarda çalışmalar yapmışlar ve fikirlerinde paralellik gözlenir. İki tiyatro düşünürü de modern anlamdaki yönetmenin oluşmasında düşünceleri etken olmuştur. "Meiningen Dükü, Rönesans'la gelen, Romantik dönemde iyice yerleşmiş olan simetrik sahne düzenini tamamen kaldırmış ve yerine asimetrik bir anlayış getirmiştir” (Aydoğdu, 1997, s. 31). O tarihe kadar boyalı panolar önünde oyunu sergileyen oyuncu artık dekor parçalarına dokuna biliyor ve oyuncunun oturabileceği somut parçalar yerleştiriliyordu.

Appia Wagner'in bu düşüncelerinden yola çıkarak Bütünlüksüzlüğün en büyük nedeni olarak iki boyutlu dekoru gördü ve bunu oyuncunun hareketini artıracak ve ufuksal zeminden düşey tasarıma bir değişim sağlayacak, merdivenler, rampalar ve platformlar gibi üçboyutlu öğelerle değiştirme önerisini getirdi. Appia, bütün bunların yanında, tüm görsel öğelerin kaynaşmasında ve bütünsel bir toplama ulaşmasında 1şı̆̆ın rolünü vurguladi (Brockett, 2000, s. 508).

Appia yaptığı bu çalışmalarla çağdaş ışık tasarımına yön vermiş bir tiyatro yapımcısı oldu. O zamana kadar üç boyut etkisi yaratılabilmek için kullanılan boyalı panolar yavaş yavaş yerini kütlesel dekor ögelerine bıraktı. Appia'ya göre oyuncu dekorun önünde değil içinde gösterisini sergilemeliydi. Appia dönemini etkisi altına alan gerçekçilik (realizm) akımının düşünsel yapısını benimsemişti. Gerçekçi sahne tasarımı sahnedeki eylemin hayatın bir parçası olduğunu hissettirmeyi hedeflerken gerçekçiliğe hizmet eden bir yanılsama yaratırken, karşı gerçekçi Wagnerci (romantik) dönem sahneleme eyleminde esas olan yanılsama daha düşsel bir atmosfer yaratımıydı bu yönüyle Appia Wagner'den ayrılıyordu. "Karşı gerçekçiler için seyircinin illüzyona girmesi demek, sahnedeki yaratıma katılması demektir. Seyirci bu şekilde düşsel bir gerçeği paylaşacaktır. Hedef "yanılsama" değil "sanrısama"dır. Appia bunu gerçekleştirmek için heyecanı atmosfere dönüştürmeye ve seyirciyi bu atmosfere katmaya çalışmıştır” (Gergin, 2013, s. 14). Appia sahne üzerinde bütünlük ve uyum istiyordu. Işık konusunda yapmış olduğu çalışmalarda hareketin değişmesiyle birlikte ışığın ve o ana uygun atmosferin yakalanması için 1 şık renklerinde değişmesi konusu üzerinde duruyordu. Wagner'in tiyatroda en çok üzerinde durduğu konu müzikti, Appia'da müziğin 1şıkla birlikte görselleşmesini istiyordu. Appia'yı sanat yaşamı boyunca etkilemiş diğer bir isimse Jacques Dalcroze'dı (1867-1950). Dalcroze geliştirmiş olduğu “euritmi” çalışmalarıyla müzik konusunda Wagner ile birlikte Appia üzerinde fikirlerin gelişmesinde etkili olmuşlardır. Euritmi’de amaç, öğrencinin müziğe karşı duyarlığını artırmaktı. Burada önemli olan, müziği yorumlamak değil, uzam sürelerine dönüştürmekti. Öğrencilerinden, bedenlerini bir çalgı gibi kullanmaları, ritimleri izlemeleri ve çözümlemeleri isteniyordu (Candan, 2003, s. 10). Appia temelde tiyatro sanatının gerçekleşebilmesi için zaman ve uzamın yeterli olacağını söylemekteydi. Appia 1904 yılında yayımlanan (light and space) "1şık ve uzam" başlıklı çalışmasında Wagner'in yazmış olduğu Nibelung yüzüğü dörtlemesinin üçüncü oyunu olan "Siegfried" ikinci perdesi üzerine bazı düşüncelerini kaleme almıştır. Bu çalışma Appia'yı anlamak için iyi bir kaynaktır. “... sahnenin düzenlenişi yalnızca Siegfried'e göre olmalı ve ormanda yaprakların hafifçe hıșırdaması Siegfried'in dikkatini yönlendirecek olursa, biz seyirciler, hareket halindeki 1şıklar ve gölgeler içinde yüzen Siegfried'e bakmalıyız, sahne arkasından harekete geçirilmiş dekor parçalarına değil" (aktaran (Candan, 2003, s. 12). Appia ile Wagner arasındaki farklı bir görüş noktası ise sahne ile alakalıydı Appia 
İtalyan sahne yapısına karşı çıkıyordu. Yanılsama konusunda gerçekliğin yanılsaması sanatı olumsuz bir noktaya taşıyacağını düşünmekteydi.

Wagner'in müziklerinden, oyunlarından ve kuramsal yazılarından oldukça etkilenen Appia, Wagner'inkiler de içinde olmak üzere operaların bildik kurgusunun, Wagner'in kuramlarını tam olarak yansıtmadığını fark etti. Yılları bulan düşünme sürecinin ardından, La mise en scene du Drame Wagnerienne [Wagnerci Oyun Sahneleme. 1895], Die Musik und die Inszenierung [Müzik ve Sahneleme, 1899] ve 1 'Oeuvre d'art vivant [Yaşayan Sanat Yapıtı, 1921] adlı yapıtları yayınladı. Bu yapıtlarında, evrensel anlamda kabul görmüş, teatral yapımla ilgili görüşlerini ortaya koydu (Brockett, 2000, s. 508).

Appia ile aynı dönemde işler üreten Edward Gordon Craig (1872-1966) 20. yy. sahne estetiği açısından önemli bir isimdir. Annesi ünlü bir oyuncu babası ünlü bir mimar ve sahne tasarımcısıydı. Onun sanat anlayışında getirmiş olduğu yeniliklerin başında görsel anlatım tekniği gelmekteydi. "Ne var ki görsel anlatıma görkem ve yanılsama adına değil de temel sanatsal anlatım aracı olarak başvurması, yeniliktir” (Candan, 2003, s. 19). Yönetmiş olduğu "Dido ile Aeneas'ta" oyununda sergilemiş olduğu yer tiyatro salonuna çevrilmiş bir konser alanıydı. İzleyicideki imgeleri açığa çıkaran yanılsamadan çok uyarmayı hedefleyen bir üslupla sahneyi tasarlanmıştı. Tiyatro salonu olmadığı için yapay bir "proskenyon" kurdurdu ve ışıkları böylece gizlemiş oldu. Yapmış olduğu çalışmada ışığa önem veren Craig sahnenin çeşitli noktalarından verilen ış1klar, arkadaki perdeyle bütünlenince sonsuz bir uzama dönüşüyordu. Craig' in kullanmış olduğu diğer bir teknikte simgesel renk kullanımıydı. Simgesel kullanımı oyunculuk tekniğinde de kullanan Craig oyuncunun mimik ve jestlerinde yansımıştır. "Dido'nun beden hareketleri, duruşları, yasın, umutsuzluğun, onurun ve yazgıya boyun eğmenin simgeleridir" (Candan, 2003, s. 20). Üretim yaptığı dönemde yıldız oyuncu kavramı ve oyuncu egolarından bunların sahnede yapılan eylemi olumsuz etkilemesinden dolayı oyuncu yerine üstün bir kukla oyuncu öneriyordu. Kişisel zayıflıkları olmayan ruhsal problemler yaşamayan bir kukla oyuncu hayal ediyordu. Döneminde bu fikirleri çok eleştirilmişti fakat çağımız sanatına düşünceleri ve etkisi hala sürmektedir. Sahne tasarımına getirmiş olduğu en büyük yenilik kütlesel mekân tasarımı yerine atmosfer tasarımını önermesiydi. Diğer bir öncül teatral kavramı ise, oyundaki sahnenin tüm bölümlerinin hareketli olması gerektiği üzerinde duruyordu. Hem zemin hem de tavan, sanatçının kontrolü altında, bağımsız olarak veya gruplar halinde sürekli değişen bir ışık düzeni içinde yukarı ve aşağı hareket ettirilebilen karelerden oluşacaktı. Böylece, bu plastik formların soyut hareketleri aracılığıyla izleyicide duygusal bir tepki ortaya çıkacaktı. Stanislavsky ile Moskova sanat tiyatrosunda sahnelemeyi düşündüğü "Hamlet" oyunundaki sahne tasarımında, birçok farklı oyunda da kullanılabilecek hareketli panolardan oluşan bir sahne tasarımı hayal etmekteydi. Fakat dönemin malzeme bilgisi ve malzeme eksikliği üstüne birde mali surun çıkınca bu tasarım tam anlamıyla yapılamamıştır. Craig'in yapmış olduğu çalışmalar 20. yüzyılda sözü edilen Stanislavsky, Meyerhold ve Brecht gibi isimleri etkilemiştir. Appia ile karşılaştığı sırada Craig masa örtüsüne ikisinin de ismini yazmış ve Appia'nın isminin altına müzik yazarak aralarındaki en büyük farkın müzik olduğunu belirtmiştir.

\section{Görsel 5}

Moskova Sanat Tiyatrosu "Hamlet” Sahne Tasarımı

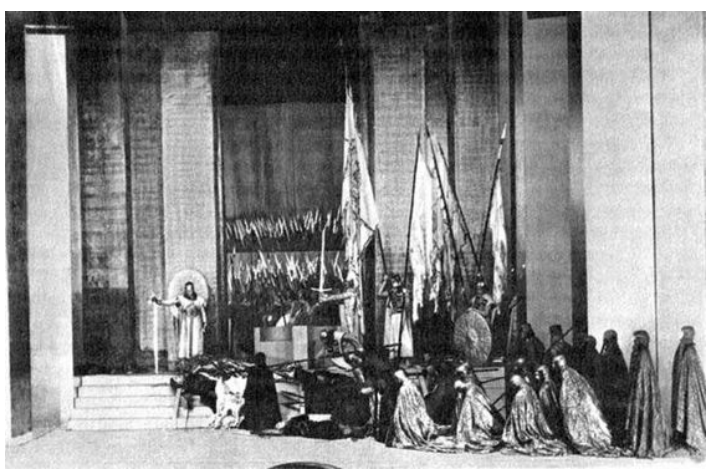

(Craig, t.y.).

19. yy.'ın ortaları ve 20. yy.'ın başlarında sanatın alışılagelmiş yapısını değiştirmek, sanatta yeni bir dil oluşturmak üzere çalışan sanatçılar ve sanat akımları kendini göstermeye başlamıştır (Tunalı, 2006, s. 13). Farklı teknik ve teknolojilerin kullanıldığı bu tür oluşumların tümüne avangard ya da tarihsel avangard akımlar denmektedir. Çağdaş sahne tasarımı konusunda birçok sanatçıyı ve düşünce yapısını etkilemiş akımların başında fütürizm gelmekteydi. Fütürizm'in (gelecekçilik) temel görüşü makineler sayesinde dünyanın daha iyi bir yer olabileceğini ön görmeleriydi. Makineleri kutsallaştıran fütüristler sanat eyleminin merkezine makine kullanımını getiriyorlardı. Fütürist sahne tasarımı bildirisini yayınlayan Enrico Prampolini (1894-1956) sahneyi yenilemeye başlamak için de tıpkı Appia gibi boyalı panolara son vererek işe başlanması gerektiğini söylüyordu. Edward Gordon Craig Fütürist sahne tasarımında diğer bir dikkat çekici unsur da Edward Gordon Craig'in üstün kukla oyuncu 
düşüncesine benzer bir düşünceyle sahnede "gaz aktörlerden" söz etmesi fütüristlerin insanların makinelere karş1 ne kadar yetersiz olduğunu düşündürmektedir. Fütüristlerin getirdiği yenilikleri Nutku şöyle aktarıyor:

Gelecekçilik, tiyatro alanında üç yeni yolun açılmasına neden olur: a. Alışılagelmiş dekor anlayışı yerine, XX. yüzyılın mekanik özelliğini verecek ve kullanılabilirliği olan iskele, köprü, basamaklar, hareket eden yüzeyler, rampalar ve renksiz bir fon ile ortaya çıkan konstrüktivist dekor kavramı, b. Yönetmenin ikinci sahne yazarı sayılması, c. Fiziksel hareketlerin esas olduğu oyunculuk anlayışı (Nutku, 2008, s. 79).

Fütürizm hareketinden etkilenen Rus avangardları konstrüktivizm akımının oluşumunda etkili olmuşlardır. Konstrüktivizm akımının başında Vsevolod Meyerhold gelmektedir. Dönemin ünlü Konstrüktivist sahne tasarımcılarıyla eserler çıkaran Meyerhold sahnede iskeleler, makine elemanları vb. ögeleri kullanarak sahne tasarımında yeni bir dil oluşturmuştur. Konstrüktivist dönem, soyutlama düşüncesi çerçevesinde şekillenen ve gelişen bir sanat görüşüyken, sadece biçimsel anlamda değil Rus sanatçılar düşünsel anlamada da yenilikçi bakış açıları getiriyorlard1.

Rus sanatçıların önderliğinde bu yaklaşım, dinamik, elektrik, 1şık ve ses elemanlarının kullanıldığ 1 otomasyonlarda kendini bulur. Dolayısıyla konstrüktivizm sadece geometrik biçimleri konu edinen bir resim anlayışından çok daha fazla kavramı ifade etmektedir. Endüstri Devrimi'nden itibaren bilimin ve teknolojinin, sosyal alandaki etkilerinin felsefeye yansımasının sanattaki göstergelerinden biri olarak da düşünülebilir (Yıldırım ve Sakalauskaite, 2011, s. 32).

Konstrüktivizm akımının önde gelen sahne tasarımcıların başında Popova, Tatlin, Malevich, Rondchenko isimleri sayılabilir. Yaptıkları sahne ve köstüm tasarımlarıyla döneminin ve kendinden sonra gelen sahne tasarımcılarının esin kaynağı olmuşlardır. Vladimir Tatlin, gündelik hayatta kullanılan bir malzemeye sahne üzerinde yer vermiş, kullandığı bu yöntemle sahne tasarımı eylemine önemli bir bakış açısı kazandırmıştır. Tatlin'le birlikte gündelik bir obje bir malzeme alelade bir poşet bile sahne tasarımı eyleminde kullanılabilir kılınmıştır. Tatlin Ayrıca "3. Enternasyonal Anıtı adında konstrüktivizm akımının simgelerinden olan bu anıtı yaratmayı düşünmüştür. Tatlin, Picasso'nun atölyesindeki kabartma ve heykellerindeki yapısalcılığı kendi sahne ve kostüm tasarımlarında uygulamıştır. Sahneyi bir inşaat unsuru olarak kullanmasıyla sahne plastiğinin alanı genişletmiştir” (Zeren, 2017, s. 80). Kısaca konstrüktivist sahne tasarımcılar yapısal şekilde olan malzemenin yalın bir biçimde sahneye taşındığı genelinde ağır ve kütlesel bir dekor yerine yapısal olarak özetleyebileceğimiz tasarımların oluşumunda etkili olmuşlardır. Konstrüktivizm sahne tasarımında kullanılan argümanlar

Çalışan insanlar, inşaat vinçleri, sigara fabrikalarının bacaları, uçaklar, trenler, motorlu arabalar, yeniyi yapılandırmada ve genç bir ülkenin tanıtımında sembolik olarak kullanılan tipik imgeler olmuştur. Burada seçilen konular ve nesnelerin neredeyse hepsinin teknolojiyle, makineleşmeyle, çağdaşlaşmayla alakalı olması, tarıma bağlı ekonomisi olan günlerin geride kaldığı ve artık günün bu değişime ayak uydurup yenilenmenin, makinanın, fabrikanın, üretimin baş tacı edildiğinin göstergesidir (Öztuna, 2007, s. 91).

Konstrüktivizm özelinde Meyerhold kendinden sonra gelen birçok tiyatro kişisine ilham kaynağ olmuştur. Bunların başında Alman politik tiyatro hareketinin kurucusu Erwin Piscator gelmektedir. Tarihsel materyalizme dayalı bir tiyatro anlayışı içerisinde olan Meyerhold'un Piscator'a esin kaynağı olduğu bilinmektedir.

Piscator tiyatroda projeksiyon teknolojisini kullanan tiyatro kişilerinin başında gelmektedir. Projeksiyon teknolojisini kullanarak çeşitli belgesel ve haber değeri taşıyan görüntüleri politik tiyatro düşüncesinin temelini oturtmuştur. Yine Piscator'un sahne tasarımı tekniğine getirdiği bir diğer yenilikse "aslan asker Şvayk oyununda kilit rol oynayan yürüme bandı olmuştur. Şvayk'ın oyun boyunca cephelerden cephelere geçişini göstermek için yürüyen bant kullanılmıştır" (Candan, 2003, s. 89). Kullanılan bu yöntemle panorama sahne tekniğinde olduğu gibi döngüsel hareket elde edilmektedir. Oyun karakterinin kullanılan yürüyen bant sayesinde cepheden cepheye hiç durmaksızın koşturup duruyormuş hissini vermesi sağlanmıştır. Piscator'un kullandığı bu yöntemler çağdaş makinelerin tiyatro sanatında kullanılmasının yaygınlaşmasını sağlamıştır. Piscator'a göre sanatsal yaratım esinlenmeyle değil düzenleme, çözüme ve kavramayla beslenmeliydi. Karşı gerçekçi bir sahne mantığı geliştiren Piscator gerçeğin sahnede yeniden yaratımı esnasında çeşitli teknolojik aygıtlara ve ekipmanlara çalışmalarında yer veriyordu. Asıl amacı politik tiyatro ile seyirciyi (halkı) Marksiz bir görüşle harekete (eyleme) geçirmeyi amaçlıyordu. Belge, film, haber gibi kaynak aldığı görselleri projeksiyon teknolojisini kullanarak seyirciyi gerçeklikle karşı karşıya getiriyordu. Piscator, politik tiyatro düşüncesinin tam anlamıyla gerçekleşebilmesi için yeni ve kendi ihtiyaçlarına uygun bir tiyatro binası yaptırmak istiyordu. Yolları Walter Gropius'la kesişen Piscator, ihtiyaçlarına uygun bir tiyatro binası tasarımını Gropius'la birlikte tasarlamaya girişmiştir. "1919'da Weimar'da Bauhaus'u kuran Walter Gropius, Erwin Piscator için hazırladığ 1 "Total Tiyatro yapısı anlayışıyla tarihteki bütün tiyatro yapılarının bir bileşimini oluşturmak istiyordu. Fakat Nasyonal Sosyalistlerin iktidara gelmesi sonucu gerçekleşme imkânı bulamayan bu tasarı, Volta Kongresi'nde sunulan bir bildiriden öteye geçememiştir" (Nutku, 1985, s. 124). Gropius'un görüşleriyle şekillenen "total tiyatro" yapısında seyirci üç ayrı biçimde tiyatro yapısının tekniğinde performans izleme olanağı buluyordu. Seyirci yerlerinin bir kısmının $\left(180^{\circ}\right)$ mekanik olarak dönmesiyle sağlanan bu sahnede oyun seyircilerin ortasında, çerçeve 
içinde ve önde oynanabilmektedir. Üç asal tiyatro sahnesi olduğunu düşünen Gropius, bunları tek bir yapıda bir araya getirmeyi amaçlamıştır. Bu sahnelerden ilki, dört yanı seyirci ile çevrili, ortada oyun yeri olan ve üç boyutlu bir sahne düzeni gerektiren çevreli tiyatrodur. İkincisi, at nalı biçiminde, basamaklı seyir yeri ve dairesel oyun yeri olan "Antik Yunan tiyatrosu” ve üçüncüsü ise tiyatro sahnesinin Rönesans sonrası gelişimi olan "çerçeve sahneli tiyatrodur” (Alpar, 2006, s. 66). Gerçekleşme imkânı bulamamış olsa da Gropius'un sahnesi modern tiyatro binalarının tasarımlarına fikir öncülüğü etmiştir” (Alpar, 2006, s. 66).

\section{Görsel 6}

Piscator İçin Hazırlanan Total Tiyatro Çizimleri

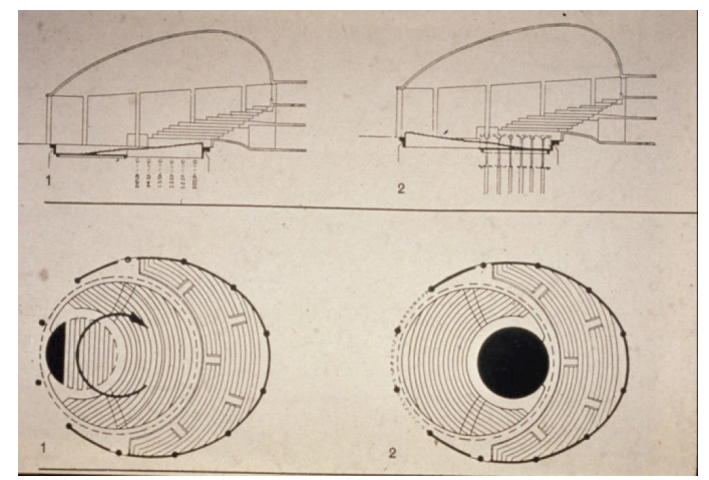

(Gropius, t.y.).

Bauhaus hareketinin temelde yapmak istedikleri şey tiyatro sahnesinin kendisini bir anlatım aracı haline getirmekti. Böylece yeni anlatım olanakları oluşmuş olacaktı. "Mimarlık tekniğini tiyatroda kullanan Bauhaus, sahneyi “ses, 1şık, uzay, biçim ve devinimin etkin yoğunlaşması olarak tanımlamıştır” (Alpar, 2006, s. 65). Tiyatro sahnesi üzerinde yoğun bir biçimde tasarımlar yapan Bauhaus sanatçıları genel olarak izleyici seyir yeri ilişkisi üzerinde durmuşlardır. İzleyicilerinde oyun mekanının bir parçası olmasın düşüncesinden yola çıkarak mekanlarını bu düşünceyle tasarlamışlardır. Gropius'un "total tiyatro" tasarımının yanı sıra Bauhaus sanatçıları Farkas Molnar'ın "U” Tiyatrosu, Andreas Weininger, Küresel Tiyatro tasarımları 'da mekânsal gerekliliğin önemini göstermektedir. Bauhaus sanatının temelde düşüncelerini şu şekilde anlayabiliriz.

Tiyatronun tözünde insan vardır. "Bauhaus" sahne estetiğinin sürekli olmaması ve ilginç deneyler olarak kalmasının nedeni "insansız" olmasıdır. "İnsansızlaştırma” eylemi, sanatta çağdaş burjuva sanatının bir özelliğidir. İnsan dışavurumcu akım içinde sökülebilen bir makine parçası gibi biçim değiştirmiş, bozulmuş, teknik araçlarla desteklenen bir kukla, anlamsız doğaüstü bir nesne durumuna indirgenmiştir (Sabankaya, 2016, s. 100).

Bauhaus’un sahne tasarımında getirmiş olduğu teknik ve teknoloji kullanımını sahnede projeksiyon sistemleri kullanarak yönetmenin projeksiyon teknolojisinin yardımıyla izleyicisinde mekanla bütünleşerek bütün duvar tavan ve yüzeylere hareketli görüntüler yardımıyla mekânsal sınırın yok edilmesi, projeksiyon görüntüleriyle yeni mekanlar oluşturabilmesi, oluşturulan görüntüsel mekanlar sayesinde de her türlü kütlesel ve boyalı panoların en aza indirgenmesi olanağını sağlayacaktır. Böylelikle de tiyatro mekânı değişken ve yanılsamalı bir oyun yerine dönüşecektir (Çalışlar, 1993, s. 134).

Çağdaş sahne tasarımında öncül deneysel çalışmalar özelliklede projeksiyon teknolojilerinin kullanımı Piscator'la başlayıp Bauhuas okuluyla devam eden projeksiyon teknolojik araçların kullanımı günümüz sahne tasarımında da önemli bir yer teşkil etmektedir. Bauhuas’un sahne tasarımcılarının projeksiyon cihazlarını kullanarak oluşturmak istedikleri mekân fikri günümüz sahne tasarımı ve gösterilerinde kullanılan sahne haritalama (mapping) yöntemine benzer bir teknik olarak gözlemlenebilir. Günümüz çağdaş sahne tasarımında kendini gösteren mapping yöntemi, ağır kütlesel dekor tasarımının yerine kullanılarak maliyetten ve zamandan tasarruf edilmesini de sağlamaktadır. Sahnede projeksiyon cihazlarını kullanarak mekân oluşturma yönteminin öncül denemelerini yapan isimler Bauhaus'un sahne tasarımcıları olmuştur. Bauhaus'un sahne tasarımcılarından "Oskar Schlemmer'in sahne boşluğunu değerlendirmede önem verdiği ilk şey çağı yansıtacak soyutlamalar olmuştur” (Alpar, 2006, s. 37). Schlemmer'e göre hacimsel mekân soyut bir mekân olarak ele alınmalıdır. Ona göre asıl mekân soyut olan değil, bedenin hareketiyle ilişkili olan mekandır.

Schlemmer insan ve mekân arasındaki ilişkiyi, insan hareketlerinin, geometrik formlarla formasyonu sonucu davranışlarının değişimi üzerinden araştırmaktadır. Sahneye ait kübik mekân yasalarını, organik insanın yasalarıyla karşılaştırmaktadır. Schlemmer'e göre mekân insana uyarlandığında, sahne doğalcı ve illüzyonist olmaktadır. İnsan kübik mekâna uyarlandığında ise sahne soyutlaşacaktır (Dervişoğlu, 2008, s. 21-22). 
Schlemmer, tasarımlarında figürü organik ve geometrik biçimlere dönüştürür. Özellikle tasarımlarında yapmış olduğu siluetleri, derin bir perspektifin olduğu boş mekânlara yerleştirir. Sanatç1, dönüştürmüş olduğu organik bedenleri basite indirgeyerek anlaş1lır kılma hedefindedir.

\section{Görsel 7}

Soyut Mekânın Yasaları ve Organik Adamın Yasaları (Oskar Schlemmer)

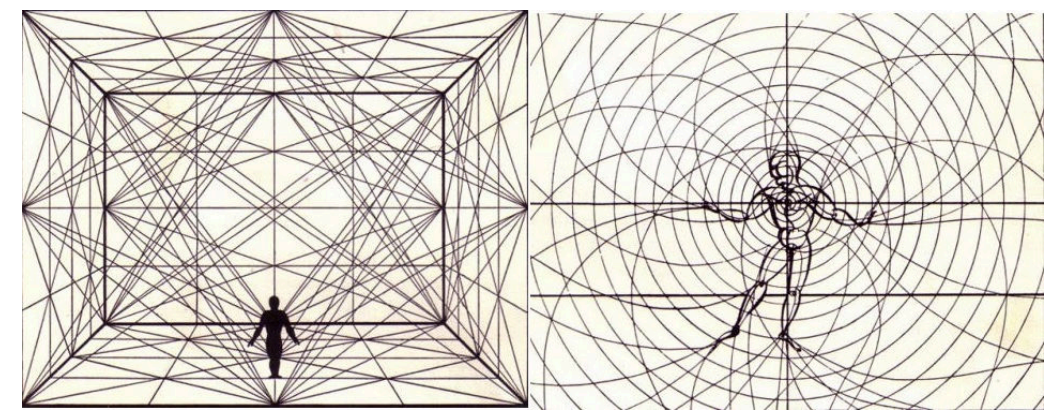

(Dervişoğlu, 2008).

Manchester Victoria Üniversitesinde sahne sanatları okuyan Prof. Steve Dixon 1991 y1lında akademisyen olarak Salford üniversitesinde göreve başladı. Çeşitli üniversitelerde sahne tasarımı alanında görev yapan Dixon'ın yazmış olduğu "Digital Porformance" alanında yazılmış en kapsamlı kitaplardan biri oldu. Ayrıca oyunculuk ve yönetmenlik de yapan Dixon, halen dijital performans alanında Brunel Üniversitesi'nde çalışmaktadır ("Steve Dixon", 2020). Sahne sanatlarında medya ve bilgisayar teknolojilerinin kullanımındaki araştırmasıyla kısa sürede uluslararası bir üne kavuştu. Yirminci yüzyıl sanat hareketlerinde teknoloji kullanımını şu şekilde bölümlemiştir. “1910'larda fütürizm, 1960'1arda karışı ortamlı (mixed media) performanslar ve 1990'1arda bilgisayar" (Dixon, 2007, s. 87). 20. Yy. sonlarında birçok teknolojik unsurun yardımıyla oluşturulmuş sanat yapıtlarında kullanılan teknik, multimedya (çoklu ortam) olmuştur. Multimedya sayısal bilgisayar teknolojisini kullanarak oluşturulmuş görüntülerin kullanımına verilen isimdir. Hiç şüphesiz günümüz sahne tasarımında da yoğun bir şekilde kullanılan multimedya unsurlarının yani görüntü teknolojilerinin temeli videonun ve fotoğraf teknolojilerinin gelişimine dayanmaktadır.

Sahne tasarımın'da dijital ve teknolojik unsurları kullanan öncül diğer bir isimse Çek asıllı Josef Svoboda'dır (1920-2002). Yedi yaşındayken amcasının ona aldığ 1 kukla tiyatrosu ile tiyatro ve sahne tasarımıyla tanışan Svoboda, babasının marangoz atölyesinde çıraklık yaptı. Bu sırada sürekli hediye edilen kukla tiyatrosunda oyunlar oynayarak ışık ve sahne tasarımları yapmaya başladı. Eğitimini Prag Konservatuarı'nda Sahne Tasarımı ve Yine Prag Uygulamalı Sanatlar Akademisi'nde mimarlık okuyarak tamamladı. 1951 yılında itibaren Çek Ulusal Tiyatronun Sanat ve Teknik işler Müdürü oldu. Svoboda yönetmen Alfred Radok ile 1958 tarihinde Belçika'nın başkenti Bürüksel'de yapılan Expo 58 sergisine Laterna Magika (Büyülü Laterna) adlı bir Gösteri ile katıldı. Sergide Çekoslovakya adına, dans, mim, ses ve ışık bir arada olduğu gösterisi büyük ilgi gördü ve dünya çapında işler yapmasını sağladı. Çek Cumhuriyeti'nin başkenti Prag'a döndüklerinde gösteride kullandıkları Laterna Magika isimli bir tiyatro kurdular. Tıpkı Appia gibi ışığa büyük önem veren Svboda: "1şık benim âşık olduğum bir malzeme. 1şıksız bir sahne uzamı yaratmak mümkün değildir" diyordu. Svoboda'nın ışıkla bu tutkulu ilişkisi, sonraları "Svoboda ışıkları" diye anılacak, ramp ışılamasını icat etmeye kadar götürdü” (aktaran Çelenk, 2007, s. 10). Svoboda'nın sahne tasarımına getirmiş olduğu yeniliklerin başında sahnede çoklu ekranlarla olan çalışmaları gelmektedir. Piscator projeksiyon teknolojisini kullanan öncül isimlerden olmasına karşın Svoboda'yı Piscator'dan ayıran özellik, projeksiyon teknolojisini mekân, uzamam ve atmosferi yaratmakta kullanması olmuştur. Sahne tasarımcısı yerine "skenograf” kelimesinin kullanılmasını istemekteydi. Ona göre sahne tasarımc1 ressam gibi değil de bir mimar gibi düşünmeliydi. Sahne tasarımcısı mekân tasarımından daha fazlasıydı 1şıkla bile birçok anlatı gerçekleştirile bilirdi. Oyun süresince değişen aksiyon ve eylemi hatta duygu, durum ilişkilerini değiştirebilirdi. Sahne tasarımına getirmiş olduğu bir yenilikse kinetik sahne olarak özetleyebileceğimiz "ufuksal, yatay ya da dikey'de herekte edebilen aynalar, platformlar, merdivenler ve geçirgen yüzeyler yaratmasıdır" (Çelenk, 2007, s. 12). Svoboda'nın geliştirmiş olduğu "Polyekran” tasarımı "çoklu ekran” olarak özetlenebilir, Josef Svoboda ve Emil Radok'la birlikte tasarlandığı ve Laterna Magika için Brüksel'deki EXPO 58'de sunulduğu bir tasarımdı. Filmlerin ve fotoğrafların bir müzik notası ile yansıtıldığı, canlı performanslar olmadan görsel-işitsel bir kompozisyon oluşturan, siyah bir alan içine dikkatlice yerleştirilmiş 8 projeksiyon ekranından oluşan bir sistemdi. "Polyvision" ise, Montreal'deki 1967 EXPO için tasarlandı. Müzikle slaytların ve film görüntülerinin yansıtıldığı, farklı görsel-işitsel kompozisyonlar oluşturan üç boyutlu hareketli nesnelerden oluşan mekansal bir yerleştirmeydi. Farklı bir buluş olan "Diapolyekran" ise, EXPO 1967'de "Creation of the World" performansıyla sunulan başka bir görsel-işitsel enstalasyon türüdür. Şov, Emil Radok tarafindan yazılmış ve yönetilmiştir. Diapolyekran sistemi, çeşitli slaytların müzikle yansıtıldığı, kompoze görüntüler, mozaikler ve pastişler oluşturan 112 küçük, bağımsız olarak dönen ekrandan oluşuyordu. Yapmış olduğu multimedya (çoklu 
ortam) çalışmalarında yurttaşı olan sahne tasarımcıların etkisi büyüktür bu isimler. "E. F. Burian ve Miroslav Kouril'dir. Kouril aynı zamanda 1957 yılında kurulan ve sahne tasarımı üzerine farklı denemelere girişen Prag Sahne Tasarımı Enstitüsü'nün de kurucusu ve yöneticisidir" (Çelenk, 2007, s. 12). Svoboda'nın yapmış olduğu çalışmalar yaşamının sonuna kadar sürmüş ve 700 üzerinde çalışmaya imza atmıştır. Yapmış olduğu malzeme çalışmalarıyla da plastik, tül, ayna, metal vb. yüzeylere projeksiyonu yansıtarak çeşitli kırılma etkileriyle gösteriler gerçekleştirmiştir. "1976'da The New York Times'da yazan müzik eleştirmeni Harold C. Schonberg, Sn. Svoboda'nın Metropolitan Opera'nın Verdi'nin "Otello"su prodüksiyonu için hazırladığı seti şu şekilde tanımladı: "Set, büyük ölçüde yatay düzlemlerde oldukça stilize, sert ve çok güzel çalışıyor" (Martin, 2002) yorumunda bulunmuştur. Svoboda Craig yatay 'da ve dikeyde kısacası sahnenin bütününde değişik açılarda herekte eden sahne düşüncesini hayata geçirmiş gibidir. Teknik ve teknolojiyi ampirik bir şekilde sahneye taşıyan Svoboda 20. yy sahne tasarımına öncül ve etkili örnekler vermiştir. Teknik bilginin yaratıcılık açısından önemini her fırsatta vurgulamıştır. Yapmış olduğu çalışmaları sınıfsal bir düzlemde anlatmak gerekirse sembolik, dişavurumcu, hatta illüzyonist olarak sahne tasarımlarını sınıflandırmak mümkündür. Josef Svoboda almış olduğu ödüllerse, Londra'daki Royal College of Arts (1969), Western Michigan University (1984) ve United States Institute for Theatre Technology'den (1986) fahri doktora unvanları bulunmaktadır. Ayrıca Chevalier de l'Ordre des Arts et des Letters (1976) ve Chevalier de la Legio Honneur, Fransa (1993) gibi ödüller sayılabilir.

\section{Görsel 8}

Diapolyekran ve Polyekran

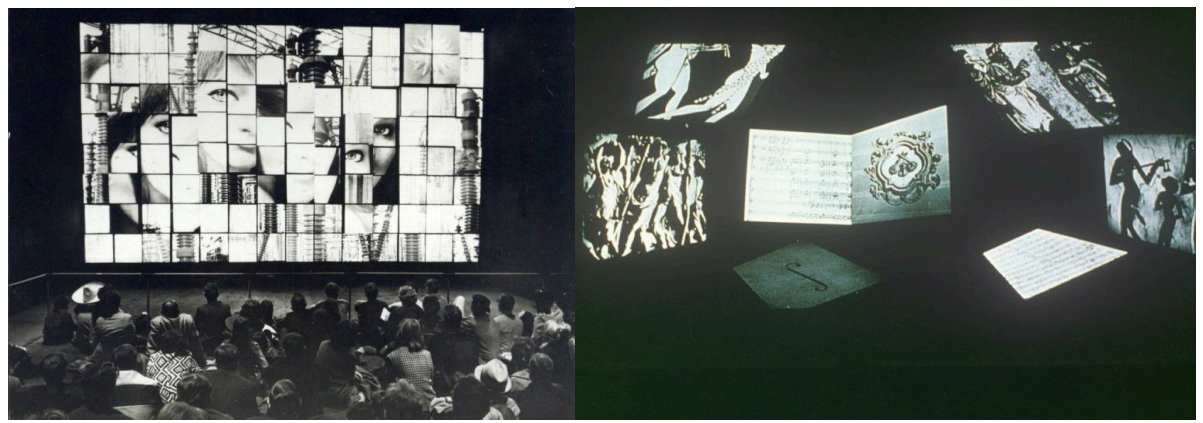

(Svoboda, t.y.)

Günther Schneider-Siemssen (1926-2015) 1940 yılında on dört yaşında dünyaca ünlü orkestra yönetmeni Clemens Kraus'la tanışmış, onun desteğiyle sahne tasarımcısı olmaya karar vermiştir. Eğitimini Almanya da Münih akademisinde yapmıştır. Eğitimini öncelikle Profesör Ludwig Sievert (Angewante Kunst) ve Profesör Emil Preetorius (Bildende Kunst) yanında yapmıştır. Etkilendiği tasarımcılar zamanın ünlü sahne tasarımcıları Casper Neher ve Teo Otto olmuştur. Herbert von Karajan'ın Wagner'in opera çalışmalarında ünlü yönetmenle birlikte çalışmışlardır. 1977-1978 yılları arasında Viyana'da Staatoperde ve Volksoper'de sahne tasarımcı gruplarının başında yer alır. Tasarımlarını oluştururken kullandığı kozmik görüntüler onun kozmik sanatla anılmasını sağlamıştır. Onun deney alanı Marionetten kukla Tiyatrosu olmuştur. Marionetten kukla Tiyatrosundaki deneyimlerini büyük tiyatrolara aktararak başarısını yakalamıştır. Sahne tasarımcısının daima yeniliklere açık olması gerektiğini söyleyen Schneider-Siemssen teknik ile tasarımlarını harmanlayarak anlatıda etkileyici tasarımlar yapmayı başarmıştır.

Yapmış olduğu sahne tasarımlarında geçmiş ile geleceği bir arada harmanlayarak iki devir arasında bir köprü kurmuştur. Teknoloji ile yapmış olduğu işlerin temel argümanları geçmişin ve doğa üstü (epik) olanın resimleridir. "Kozmik bakış bilinen dünyevi aşktan ziyade tanrısal aşkın ifadesidir. Tanrı ve tanrısal olan ışığın azametiyle anlatılır" (Çevik, 2007, s. 44). Projeksiyon cihazının pahalı olması onun yaptığı ilkin çalışmalarında kendi projeksiyonunu yapmaya itmiştir. Bir sahne tasarımcısı için tekniğin önemini her firsatta vurgulayan Siemssen cam yüzeylere çizdiği fon görüntülerini çeşitli ışıklar aracılığıyla yansıtarak kendi projeksiyonunu oluşturmuştur. Her ne kadar yapmış olduğu ilkin yenilikçi çalışmalarla eleştirilere maruz kalsa da bununla ilgili sorulara şöyle yanıt vermiştir.

"Sahne tasarımının bütününde teknik gereklidir, ama tekniği birebir sanata katılmasından yana değildir. Sanatsal olanı sahnede desteklemek için teknolojiyi kullanmıştır. Bilakis çıkış noktam daima tiyatro parçalarında, gösterideydi. Dramaturg belli olan parçayı sahnede çözüyordu. Sahnede gerçekleşecek olanı ve talep edileni teknikle çözmek gerekliydi” (Çevik, 2007, s. 85).

Onun sahne tasarımına getirdiği başka bir yenilik ise hologram teknolojisindedir.

“Yüzyılımızda holografiyi Macar Denis Gabor'icat etti. Benimle sahne tasarımında gelişti. Newyork müzesinde ilk denemelerini gördüm. Hologram beni büyüledi, resimdeki üç boyutlu görüntüyü gördüm. Bir anda yüzeyde 
derinlik yaratarak insana düşünce sıçrayışı yaşatmaktaydı. Nesneler, önünüzde duruyor, dokunmak istiyorsunuz fakat dokunamiyorsunuz" (Pahlen, 2001, s. 154).

"Kozmik bakış bilinen dünyevi aşktan ziyade tanrısal aşkın ifadesidir. Tanrı ve tanrısal olan ışığın azametiyle anlatılır" (Çevik, 2007, s. 44). Günther Schneider-Siemssen sahne tasarımına getirmiş olduğu en büyük yeniliklerden biri de tasarımlarında lazer teknolojisini çok iyi bir biçimde kullanarak dramatik etkiyi artırması ve yeni anlam ve anlatım araçları oluşturmasıdır.

\section{Görsel 9}

Mystery-Musical von Georg Stampfer

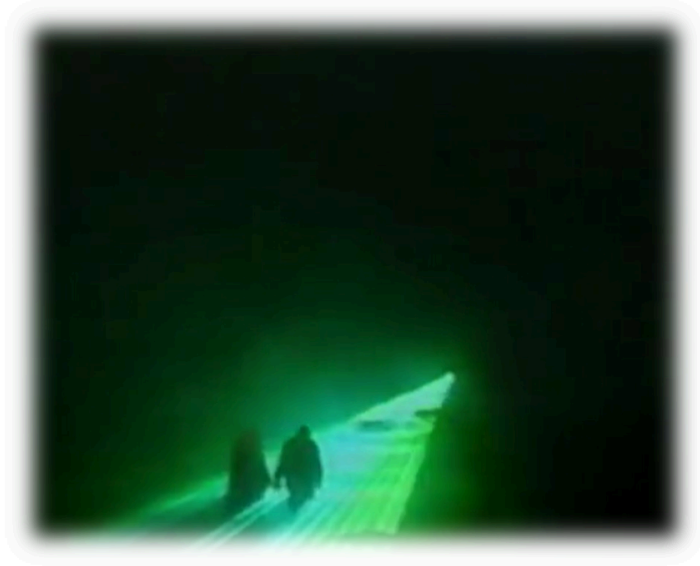

(Schneider Siemssen, 1995/96).

Kozmik tasarımlarında ele aldığı biçim insan doğa insan evren birlikteliğinin bize göstermektedir. Sahnedeki oyuncu dekorun içinde bazen kaybolup bütünleşirken bazen de devleşerek varolmuştur. Tasarımlarında anlatıyı sağlamak için dönemin ışık ve görsel teknolojilerini kullanmıştır. Kozmik tasarımlarında fonlara yansıtmış olduğu galaksi gezegen görüntüleri aslında bize insanın yapmış olduğu savaş ve kötülüklerin bir hiç olduğu insanın evrende aslında çok küçük bir yere sahip olduğu gerçeğini anlatmaktadır. Tasarımlarında farklı açılarda oyunu izleyen seyircilere aynı ölçüde bakış açısıyla izleme firsatı sunmuştur. Schneider- Siemssen'nin önemli tasarım özelliklerinden biri de budur. Genellikle opera sahne tasarımlarında yuvarlak dairesel formlar kullanmıştır. Kullanmış olduğu bu formları açıklarken de galaksi sistemlerindeki dairesel formlardan örnekler vererek bağ kurmuştur. Onun yapmış olduğu 1şık ve görsel tasarımlarda kullandığı iki boyutlu materyalleri üç boyutlu hissi uyandıracak şekilde uygulaması başarasının sırlarındandır. Tiyatroda projeksiyon teknolojisini kullanımında bulunan ilk kişi Erwin Piscator olmuştur. Politik tiyatrosunda gazete haber ve görüntülerini çeşitli yüzeylere yansıtarak bir anlatı dili oluşturmuştur. Schneider- Siemssen'nin projeksiyon teknolojisiyle yaptığı şey ise o güne kadar denenmemiş bir durumdur. Çeşitli görselleri boyut hissi verecek şekilde fonlara yansitarak hem atmosferde hem de anlatıda doğa üstü görüntü ve sahne tasarımları sağlamıştır. Bu yönüyle mapping tekniğini kullanan öncül isimlerden olduğu söylenebilir. Tasarımlarında sürrealist bir atmosfer göze çarpmaktadır. Tasarımlarını yaparken fantezi üzerinde durmuştur. Ona göre fanteziden uzak bir sahne tasarımcı başarıya ulaşamaz. Fanteziye ulaşmak için bazen tıpkı bir bilim adamı gibi hareket eder. Tasarımlarındaki diğer bir özellik ise semayı boş bırakmasıdır. Zemine ağırlık verirken atmosfer yaratmak için fonu boyar ya da görsel yansıtır. Boyamalarda ve yansıtmalarda kullandığı teknolojik argüman olan projeksiyon cihazı onun bilimsel yanını ortaya çıkartır. Günümüzde kullanılan mapping (haritalama) teknolojisinden farklı olarak mekân yaratma genellikle projeksiyon cihazlarıyla atmosfer oluşturur. Mekân yaratımında kullandığı teknolojik yenilik hologramdır. Hologram teknolojisini kullanarak mekânsal parçalar yaratır. Örneğin bir sütün bir ağaç vb. ögeleri hologram teknolojisiyle tasarlayarak sahneye getirmiştir.

$\mathrm{Bu}$ teknikler, sinemanın gelişimi anlatım ve teknik açıdan tiyatro sanatını ve özelinde sahne tasarımını etkilemiştir. Video teknolojisinin gelişimi ve televizyon cihazının bulunuşuyla birlikte hız kazanan görüntü teknolojileri, anlatım araçlarının çeşitlenmesiyle yeni sunum olanakları sağlamıştır. Sanat alanında da kullanımı gerçekleşmiş olan video teknolojisi Güney Koreli “fluxsus” sanatçısı Naum June Paik tarafından video art olarak tanımlanmıştır. "Günümüz tiyatro gruplarından olan New York merkezli "The Wooster Group" televizyon teknolojilerinde kullanılan açık ve kapalı devre yayınları kullanarak tiyatro oyunları sergilemektedirler. "Our Town” (bizim şehir) adlı oyunlarında tavandan televizyon ekranları sarkıtarak çeşitli görüntülerle oyunu sergilemişlerdir" (Şeyben, 2016, s. 49). 


\section{Görsel 10}

Bizim Şehir (Our Town)

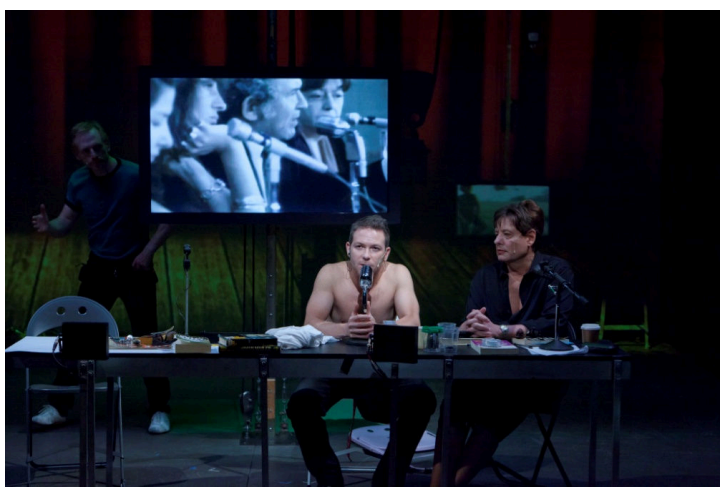

(The Woost Projects, 1982).

Günümüz sahne tasarımlarında teknolojiyi yoğun bir biçimde kullanan diğer önemli bir isimse Kanadalı Yönetmen, oyuncu ve yazar olarak bilinen "Robert Lepage" dir. Kurmuş olduğu Ex Machina adındaki tiyatro topluluğuyla yoğun bir şekilde teknolojiyi kullanarak tiyatro oyunları sergilemektedir. Lepage Needles and Opium (İğne ve Afyon) adlı oyunda projeksiyon teknolojisini kullanarak,

Miles Davis‘in hayatını aktarmak için videoart'ta trompet parçaları, kol saati, eroin paketi ve şırınga kullanır. Ve seyirci böylece, başka hiçbir şey görmese bile Miles Davis‘in nasıl bir hayat yaşadığını ve öldüğünü kolaylıkla zihninde canlandırabilir. Tokyo'da Hiroşima'ya atılan atom bombasıyla ilgili yaptığı oyunda da dekor yerine çokça ekran kullandığını okuduğumuz Lepage, bazı eleştirmenler tarafından bir süre sonra metinlere sürekli biçimsel yaklaşması konusunda eleştirilmiş, kimi sanat insanları da sahnelemede yeni bir dil yakaladığı üzerinde 1 srarcı olmuştur... Günümüze bakıldı̆̆ında ise teknolojinin kullanılmadığı sahneleme yok denecek kadar azdır. Teknolojinin ucuzlaması ve yaygınlaşması, sanatçıların bunları işlerine daha rahat dahil etmesine olanak sağlamıştır. İfade olanaklarının gittikçe daraldığı günümüzde yeni ifade biçimlerinin geliştiğini görmek mutluluk verici (Tirben, 2018, s. 25-26).

\section{Görsel 11}

İgne ve Afyon (Needles and Opium)

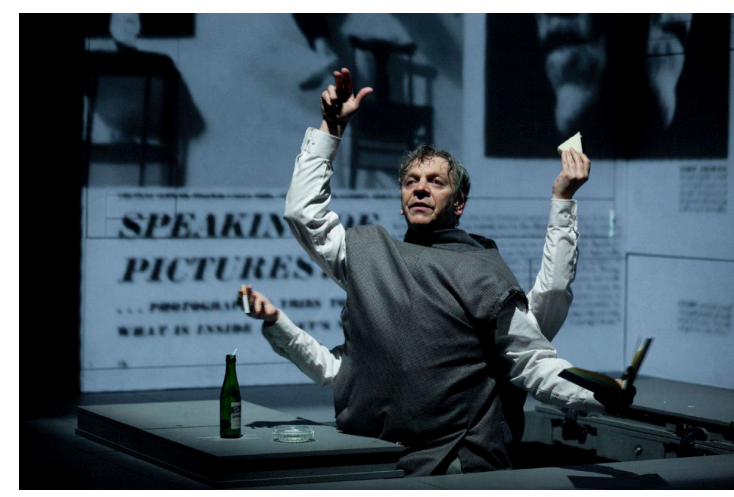

(Lepage, 1991).

Çalışmalarında teknoloji kullanan diğer bir isimse Esmeralda Es Devlin'dir (1971) İngiliz sahne tasarımcısı Devlin yapmış olduğu sahne ve set tasarımlarıyla dünyada tanınan bir tasarımcı oldu. Müzik ve edebiyat eğitimi alan Devlin katılmış olduğu sahne tasarım kursuyla sahne tasarımı ile tanıştı. Küçük bir İngiliz tiyatrosunda ilk tasarımını yapmasıyla büyük başarıya imza atan Devlin "o küçük alanda dönen bir sahne inşa etti, projeksiyonlarla mucizeler yarattı. Üstelik sahne tasarımına çok para harcanırken tüm bunları çok ucuza mal ediyorlardı. Devlin tasarımın her yerinde yer aldı. Boyama, sökme, taşıma ve hatta kaynak yapma” (Yılmaz, 2019) yapmış olduğu sahne ve set tasarımlarında teknik ve teknolojiyi etkin bir biçimde kullanmasıyla birçok kişinin aradı̆̆ bir isim haline geldi. Tasarım yaparken "Mekân, bir yap-boz bulmaca gibidir. Sadece doğru parçaları araştırmayla bulup yerlerine yerleştirmek gerekir." (It's Nice That, 2015). Demektedir. Abstract isimli Netflix'in belgeselinde şunları söylemekte, "Çalışmamın son 20 yılında nesnelerin genellikle boşlukları doldurmak için yapıldığını keşfettim. Benim için bu boşluğu sanatla doldurma dürtüsü esastır" (aktaran Yılmaz, 2019) demiştir. Az aslında çoktur söylemiyle tasarımlarını gerçekleştirdiği gözlenen Devlin tasarımlarına başlamadan önce uzun süreli gözlemler ve görsel araştırma süreçleri geçirmektedir. Yapmış olduğu "Macbeth" opera çalışmasında "sahne, çapraz olarak 
yerleştirilmiş aynalarla bir illüzyon kutusu olarak ele alınmıştır. Bir tarafı gerçek zamanda olan olayları gösterirken, aynanın öteki tarafında Macbeth'in zihninde olan biten gösterilmiştir. Bu teknik Viktoryan sihirbazların hayalet yaratmak için kullandıkları bir mekanizmadır" (Çevikayak, 2016, s. 388). 2003 yılında yapmış olduğu ilk konser set tasarımı olan "flag:burning” te içerisi gözüken, kapalı küpler içine yerleştirmiş olduğu müzik gurubu üyelerinin küplerin ön yüzeylerine projeksiyonla yansıtmış olduğu kalp atışları, beyin taramaları, burun/ağız/göz gibi vücut parçalarını göstererek o güne kadar set tasarımlarında denenmemiş bir tasarım sunmuştur. Yapmış olduğu bu çalışmada gurup üyelerinin kompozisyon olarak sanki bütüncül bir varlığını yaratmıştır. Profesyonel set tasarımına rap şarkıcısı Kenye West ile adım atan Devlin on yılı aşkın süredir. Dünyaca tanınan birçok şarkıcının set tasarımlarını yapmaktadır. Bunlardan birkaçını sayacak olursak, Adele, Lady Gaga, Beyonce, Lorde, Weeknd, Take That, U2, Muse gibi isimlerle çalışmıştır.

\section{Görsel 12}

Wire-Flag:Burning Set Tasarımı

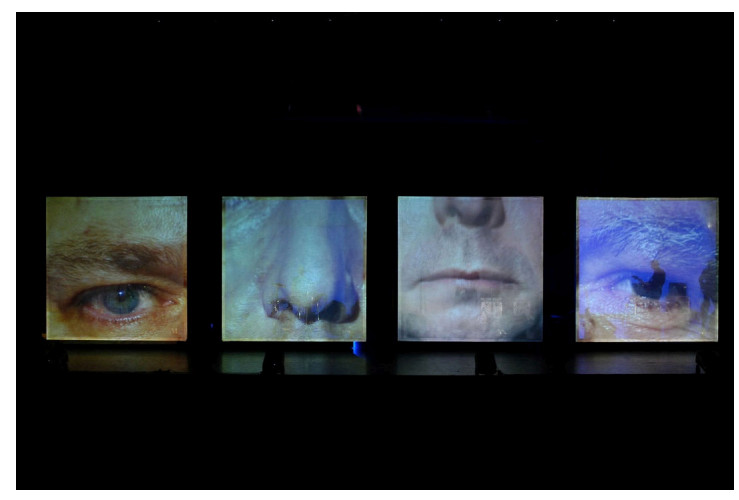

(Es Devlin, t.y.).

Günümüz sahne tasarımı alanında yapımlarında teknolojiyi kullanan diğer bir isim de Robert Wilson'dur (1941). Yapmış olduğu imge tiyatrosuyla büyük bir ilgi ve tanınırlığa ulaşan Wilson'un yapımlarında ilk etapta göze çarpan özelliklerin başında yavaşlık, tekrarlar, tablolar ve teknoloji kullanımı gelmektedir. Oyunlarında sahnelerin genelinde bir resim çerçevesinde oluşmakta olan görseller görülür. Oyunlarındaki yavaşlık ile ilgili gelen eleştirilere ise "oyuncu bu yavaşlığı haklaştırabiliyorsa bunun sahne üzerinde anlamı olacağını; zamanlama kavramının deneyimle belirlendiğini, önemli olanın enerjinin hangi hızda ve aksiyonla en doğru şekilde sahneye aktarılmasının belirlenmesi olduğunu ifade etti" (Kaleli, 2016). İzleyenlere yaşattı̆ğ imgelem yağmurunun sebebini babasının televizyon izlerken kanallar arasındaki hızlı geçişlerine bağlayan Wilson "Kafam kanaldan kanala gecen bir televizyon gibi çalışıyor, bir düşünceden bir başka düşünceye, bir sözcük kümesinden bir başka sözcük kümesine, bir kanaldan bir başka kanala atlarcasına geçiyorum” (İpşirlioğlu, 2004, s. 76). Oyunlarında oyuncuyu sahnedeki diğer unsurlar gibi bir araç olarak gören Wilson yapılan eylemin bütün unsurlarıyla ahenk ve düzen içinde olması gerektiğini savunmaktadır. Teknolojik unsurlarla oyuncuların yarattığı kompozisyonları birer tabloya benzeten Wilson günümüz teknolojik aletlerinden projeksiyon cihazları, gelişmiş 1şık teknolojileri, ve sahnedeki mekanik unsurlardan yoğun bir biçimde yararlanmaktadır. Projelerine başlarken ilk çözümlediği şeyin 1şık olduğunu belirten Wilson “Einstein'ın “Işık her şeyin ölçümüdür.” sözünün felsefesini benimsediğini belirtti” (Kaleli, 2016). Yapmış olduğu sahne tasarımlarıyla gerçek dünya görüntüsünü kırarak farklı bir boyut ve uzamda görseller oluşturan Wilson üç boyutlu sahne görüntüsünü iki boyuta düşürerek "pitoreks" sahne tasarımını daha da belirgin bir hale getirmiş olur.

\section{Görsel 13}

Garrincha Operasindan Bir Kare

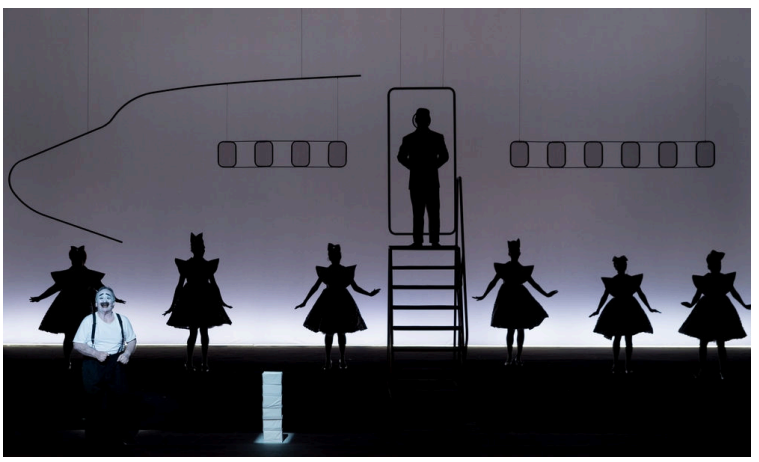

(Wilson, 2016). 
Çağdaş sahne tasarımında kullanımı denenmeye başlanan diğer bir teknolojik unsursa "Virtual Reality" (sanal gerçeklik) teknolojisidir. Günümüzde özellikle National Theatre (ulusal tiyatro)'nun "Rufus Norris" yönetmenliğinde yapmış olduğu denemeler ve "TheatreVR" yapmış olduğu çalışmalar sayesinde tiyatro sanatında günümüz sanal gerçeklik ve zenginleştirilmiş gerçeklik teknolojik unsurların kullanımı konusunda hızlı bir yol kat edilmektedir. "İlk defa sanal gerçeklik kavramını, 1970'li yıllarda Jaron Lenier tarafından kullanmıştır. Latince kökeni "virtualis" olan sanal gerçeklik var olmayanın, bilgisayar yazılım ve donanımları ile oluşturulan üç boyutlu dünya ile etkileşimimizi sağlayarak gerçek dünyadaki hissedilebilen objelere dönüşmesi için kullanılır. Sanal olan bu objeler sanal ortam aracılığı ile iletişimde bulunduğumuz gerçekte varmıș algısı oluşturan bir ortama dönüşür" (Bayraktar ve Kaleli, 2007, s. 3).

ZG tiyatrosunu hayal ederken, dekorun yarattığı sahne atmosferi akla gelen en önemli ve sahnelemeyi en çok etkileyecek değişimdir. Bu değişimi algılayabilmek için günümüz ZG uygulamalarından bir örnek vermek uygundur. Doğa olaylarının, nesli tükenmiş canlıların ve vahşi hayatın gerçek mekân ve insanlarla etkileşiminin sağlandığı National Geographic Channel'ın Appshaker firması tarafından insanın dünya olayları ve içerikleriyle etkileşiminin kolayca sağlaması için yaptığı projede ZG kullanılarak insanları yunuslar, dinazorlar, yer oluşumları, doğa olayları sahnelerinin içine sokan bir ortam yaratılmıştır. Kullanıcı ortamı bir dev ekran üzerinden gözlemleyebilmektedir (Özdemir, 2012, s. 57).

Yeni bir teknoloji olan sanal gerçeklik kavramı tiyatro sanatında anlatı dilini görsel etki ve görsel efektleri şu an hayal edilemeyecek bir boyuta taşımaktadır. Bilgisayar ortamında hazırlanmış tasarımsal argümanla bir başlık veya bir gözlük yardırmayla izleyicinin gözünden beynine iletilmektedir. Beyinde oluşan görüntünün her ne kadar gerçek olmadığı algısı biliniyor olsa da gelişen teknolojik yapı sayesinde bir süre sonra gözden beyine iletilen görüntü sinyalleri gerçek gibi algılanmaya başlanır. Şu an deneme aşamasında olan bu teknolojik yenilik belki de ileri bir gelecekte tiyatro sanatının gösterim şeklini değiştirebilir hale getirecektir. Birçok sektörde kullanılan sanal gerçeklik teknolojisi gelecek açısından umut veren bir teknoloji olarak nitelendirilmektedir.

\section{Görsel 14}

TheaterVR Kalevala.Episodes Teaser

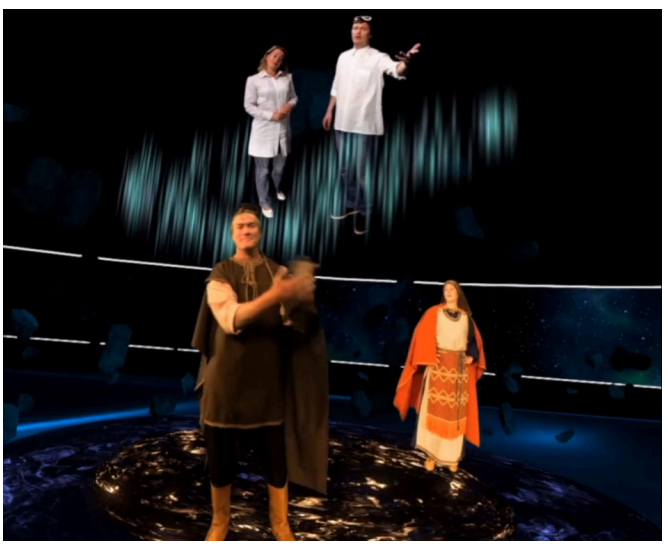

(TheaterVR, t.y.).

Günümüz sahne tasarımında ve performanslarında teknolojiyi kullanan diğer isimler arasında, "Richard Foreman, Robert Wilson, Peter Brook, Robert Lepage, The Wooster Group, Jan Fabre, Forced Entertainment, Rachel Rosenthal, Tim Miller, Mabou Mines, Station House Opera, Laurie Anderson, Meredith Monk, Peter Sellars, Unda Montano, Squat Theatre, Lee Breuer, John Jesurun, George Coates, Blast Theory, Joan Jones, Moving Being, God Squad, Forkbeard Fantasy, Desperate Optimists, Yvonne Rainer, Trisha Brown, Lucinda Childs, La Fura DelsBaus, Guillermo gomez-Peiia ve Ping Chong siralanabilir” (Dixon, 2007, s. 104).

Olafur Eliasson (1967- Danimarka-İzlanda) ve Refik Anadol (1985- İstanbul) isimlerinden de bahsetmeden geçmek doğru olmayacaktır. Eliasson yapmış olduğu sanat çalışmalarında sşık, su ve hava sıcaklığı gibi temel malzemeleri kullanan heykeller ve büyük ölçekli enstalasyon çalışmaları yapmaktadır. 1989-1995 yıllarında Danimarka Kraliyet Güzel Sanatlar Akademisi'nde okudu. Sanatçı Christian Eckhart'ın stüdyosunda asistan olarak çalıştı. Eğitimin bitmesinin ardından 1995 yılında, Berlin'e taşındı. Berlin'de bir mekânsal araştırma laboratuvarı olan Studio Olafur Eliasson'u kurdu. Olafur, 1998 ve 2001 yıllarında birçok şehirlerde yapılan "Yeşil Nehir" müdahalesi de olmak üzere kamusal alanda birçok projeye gerçekleştirdi. "Eserlerinin çoğu gibi, heykel de sanat ve bilim arasındaki ortak zemini araştırıyor. Kara deliklerden ve galaksilerden deniz kabuklarına ve DNA bobinlerine kadar bulunan doğal formları hatırlatan bir toroid şeklinde kalıplanmıştır” (Aydın, 2020). Olafur, 2009-2014 yılları arasında Berlin Sanat Üniversitesi'nde profesör olarak görev yapmaktadır. 2014'ten beri Addis Ababa'daki Alle Güzel Sanatlar ve Tasarım Okulu'nda yardımcı profesör unvanı ile çalışmaktadır. Doğayı taklit 
ettiği optik yanılsama ile kurgulanmış sanat eserleri üretti. 2007'den beri, Studio Olafur Eliasson'da mühendis, Mimar, araştırmac1, müzisyen sanat tarihçisi ve asistanlardan oluşan kadrolu ekibi ile stüdyosunda üretimlerine sürdürmektedir. Eliasson, 2003 y1lında Londra'da "Modern's Turbine Hall'da The Weather" hayata geçirdi. "Enstalasyon, güneşi ve gökyüzünü temsil ediyor. İnce bir sis, ortama nüfuz ediyor ve gün boyu, bulutsu oluşumlarla birikiyor. Eliasson'ın tavanın kaybolduğu hissini yarattığı salonda, uzak bir köşeye konumlandırdığ yüzlerce mono frekanslı lamba bulunuyor. Oluşan yarı dairesel form ile gerçek alanı, yansıma yoluyla birleştiriyor" (Aydın, 2020). 2014 yılında "Inside the Horizon' adlı enstalasyonunda müze binasının karşısındaki yüzeylere, aynalar ve sarı cam karolarla kaplı, içeriden aydınlatılmış 43 üçgen sütun yerleştirdi. Böylelikle, ziyaretçiye sürekli değişen 1şı perspektifleriyle, bir tür gölge ve yansıma oyunu sundu" (Aydın, 2020). Eliasson yapmış olduğu çalışmalarda teknoloji ve doğayı harmanlayarak çevreci sanat eserleri üretmektedir. Atmosfer ve uzam konusunda gelișen teknolojileri etken bir biçimde kullanan Eliasson yapmış olduğu çalışmalarla sahne tasarımı alanında üretim yapmamış olsa da ürettiği sanat eserleri, sahne tasarımı konusunda ufuk açıcı olabilir.

\section{Görsel 15}

The Weather Enstalasyonu

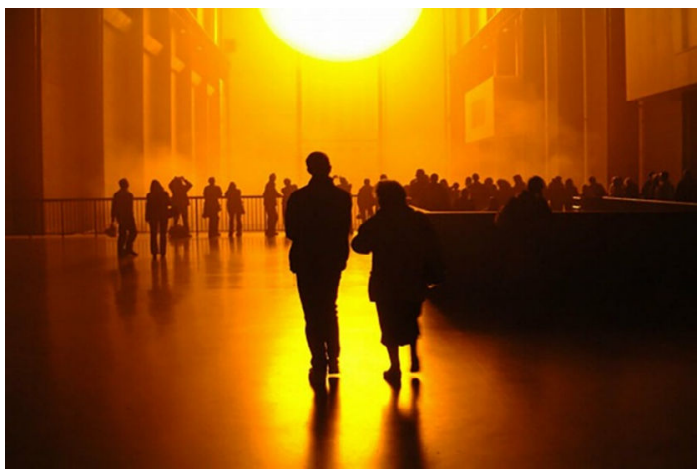

(Eliasson, 2003).

\section{Görsel 16}

Inside The Horizon Enstalasyonu

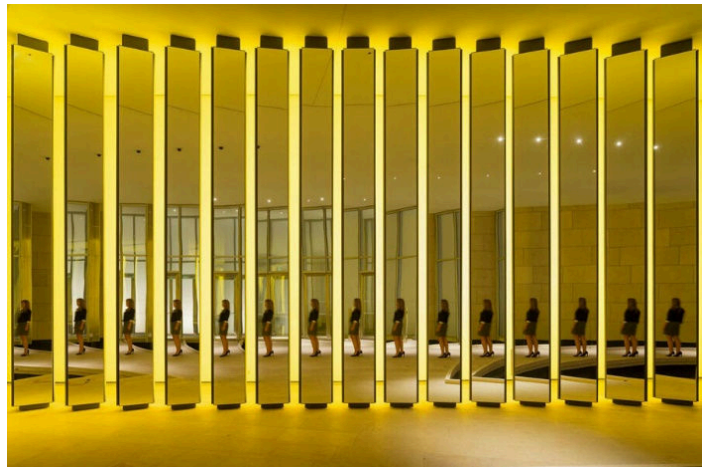

(Eliasson, 2014).

Refik Anadol yapay zekâyla üretmiş olduğu sanat eserleriyle öncül bir sanatçı olarak tanınmaktadır. Parametrik veri heykel yaklaşımı ile mekâna özgü kamusal sanat ve sürükleyici yerleştirme yaklaşımında bulunmaktadır. Canlı ses ve görsel performans alanlarındaki çalışmaları, mimari ve medya sanatları arasında hibrit bir ilişki oluşturarak dijital ve fiziksel varlıklar arasındaki alanı araştırmaktadır. Los Angeles, California Üniversitesi'nde Medya Sanatları alanında güzel sanatlar, İstanbul Bilgi Üniversitesi'nde Görsel İletişim Tasarımı alanında güzel sanatlar yüksek lisansının yanı sıra fotoğraf ve video alanında yüksek lisans derecesine sahiptir. Yapmış olduğu çalışmalarında Medya sanatlarını mimariye katarak, artık dijital olmayan gerçeklerin olmadığı bir dijital mimari sonrası gelecek olasılığını sorgulamaktadır. Anadol'un çalışması, tüm mekânların ve cephelerin medya sanatçılarının tuvali olarak kullanılma potansiyeline sahip olduğunu öne sürmktedir. Temelde sorunsallaştırdığ 1 şey, teknolojinin sınırlarını zorlayarak yeni dünya görünüşünün örneklerini vermeyi amaçlar. Milyonlarca görseli big data olarak depolayan ve yapay zekâ teknolojisiyle harmanlayarak yeni bir görsel dil oluşturan Anadol, sanatın geleceğine dair ip uçları vermektedir. Anadol her ne kadar sahne tasarımı alanında işler üretmemiş olsa da, her alanda yavaş yavaş hayatımıza girmekte olan yapay zekâ teknolojisiyle sanat bağlamında nasıl üretimler yapılacağına dair ip uçları vermektedir. 


\section{Görsel 17}

Machine Hallucination

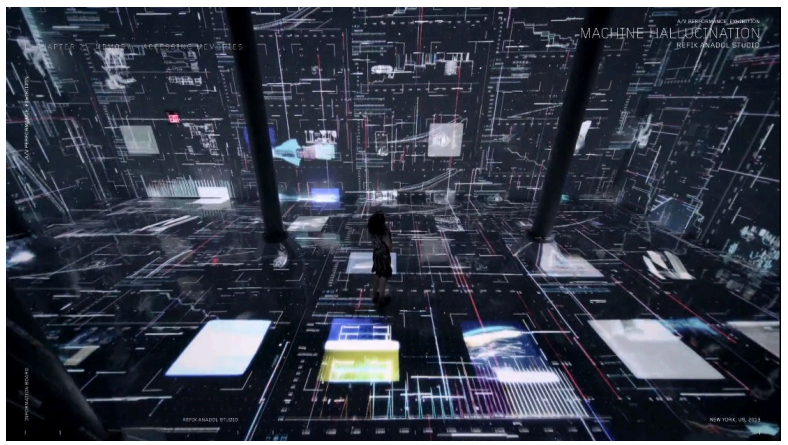

(Anadol, 2019).

Son olarak çalışmamızda yapay zekâ teknolojisiyle geliştirilmiş bir yazılım olan "DALL-E" den söz edeceğiz. DALL-E NLP (Natural Language Processing) tabanlı bir yapay zekâ teknolojisidir. "OpenAI" firması tarafindan geliştirilen bu dil modelinde sözlü olarak aktarılan kelimeleri görsel olarak tasarımlara dönüştürmektedir. OpenAI firmasi ilk olarak "NLP modellerinden biri olan GPT-3 "Generative Pre-trained Transformer 3" geliştirmiştir. Gpt3 modeli 175 milyar parametreye ile veri işleme kapasitesine sahip bir teknolojidir. Gpt-3 ile "makale yazabilmekte, röportaj yapabilmekte, grafik üretebilmekte, kod yazabilmekte, soru üretebilmekte ve hatta belirli konularda eğitim verebilmektedir. Bu da NLP teknolojilerinin geldiği noktayı gösterir niteliktedir" (Fırat, 2020, s. 534). DALL-E ise, Hayvanların ve nesnelerin "antropomorfize" edilmiş versiyonlarını oluşturma, ilgisiz kavramları makul şekillerde birleştirme, metin oluşturma ve mevcut görüntülere dönüşümler uygulama dahil olmak üzere çeşitli yeteneklere sahip olan bir modeldir. DALL-E GPT-3'ün 12 milyar parametreli bir sürümüdür. "DALL-E, aynı zamanda cümle içerisindeki pozisyon bilgilerini, malzemeleri, nesneler arası ilișkileri ve nesnelerin kendileriyle ilgili özelliklerini diğerleriyle karıştırmadan anlayıp, uygun bir şekilde işleyebiliyor" (Erbas, 2021). DALL-E tam olarak mimariden, endüstriyel tasarıma ve modaya çeşitli alanlarda üretim yapabilmekte. Ürünlerin şekil, renk, desen, doku vb. gibi kelime girdileriyle üreten bir yapay zekâ modeli. Örneğin avokado şeklinde bir koltuk tasarımı yapmak istediğimizde DALL-E bunu söylememiz yeterli, sadece koltukta değil altıgen desenli bir saat tasarımı isteyelim ya da aklınıza gelen herhangi bir nesneyi görüntüyü DALL-E sayesinde tasarlamak mümkün. Yapay zekanın bu denli hızlı ve mantıklı tasarımlar yapabilme kapasitesi, ilerleyen dönemlerde sahne tasarımı alanında da kullanıla bilir bir teknoloji gibi durmakta.

\section{Görsel 18}

DALL-E’nin Görselleştirdiği Alp Salyangoz Resimleri

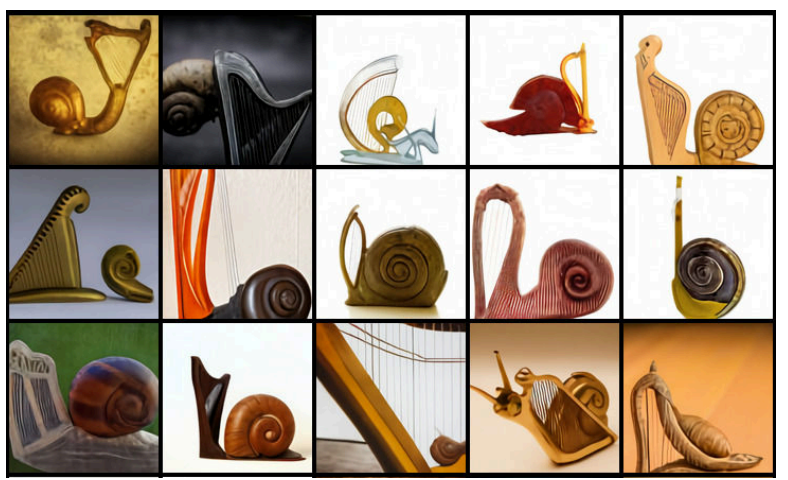

(OpenAI, t.y.).

\section{Sonuç}

Teknik anlamda kullanılan cihaz ve teknolojilerin yanı sıra sahne tasarımının hayata geçirmedeki ön aşamalarından olan çizim eylemiyse 1990'lardan sonra bilgisayar teknolojisinin hızla gelişip ulaşılabilir hale gelerek sayısal teknolojileri kullanıp programlar yaratılmasıyla eskiden kâğıt kalemle yapılan tasarlama eylemi bilgisayar ortamıyla yapılır olmaya başlamıştır. Özellikle CAD (Bilgisayar Destekli Tasarım) yazılımlarıyla sahnedeki bileşenlerin iki boyutlu çizimi ve üç boyutlu modellemelerinin daha kolay yapılabilmesi mümkün hale gelmiştir. Bilgisayarda yapılan çizimler, sahnede kullanılacak herhangi bir dekorun istenildiği gibi düzenlenip 360 derece açıyla incelenmesini sağlamaktadır. 
Günümüz sahne tasarımcılarında, eserlerinde dijital dili kullanan ve beğenilen, izleyici başarasını yakalamış özellikle sahne tasarımı alanında yenilikler kullanmış yukarda isimlerini saydığımız kişiler. Sahne Tasarımlarında dijital ve gelişmiş teknik olanaklarla tasarım eylemini gerçekleştiren, kullandıkları yöntem ve materyallerle sahne tasarımı eylemine deneysel bakış açıları kazandırmışlardır. Hızla Gelişen bu teknolojik çağda çalışmamızdaki bulgularda da görülmektedir ki tiyatro özelinde sahne tasarımı alanında geçmişten günümüze kullanılan teknik ve teknolojik yenilikler her çağın kendine ait sosyal ekonomik ve kültürel yapısına paralel olarak gelişim ve değişim göstermektedir. Antik Yunan tiyatrosunda kullanılmaya başlanan vinç sistemleri o günkü teknik olanaklar bakımından teknolojik olarak nitelendirilebilir. Onu takip eden dönemde kiliselerin içinde oynanan tiyatro oyunlarındaysa efektlerle illüzyonu yaratıp seyircide zenginleştirilmiş bir görsel, inandırıcı bir eylem oluşturulmaya çalışılmıştır. Günümüze gelindiğinde ise insan beyinin tam olarak algılayamayacağı bir hızda teknoloji gelişmekte ve değişmektedir. Her çağda olduğu gibi günümüz tiyatrosunda da bu teknolojik gelişim ve değişim gözlenmektedir. Gerek biçimsel gerekse doğrudan bir anlatım aracı olarak süre gelen sahne tasarım eylemi teknik ve teknolojik yenilikleri kendi anlatı dilene empoze ederek hem anlatı hem de biçimsel olarak teknolojiyi kullanmışlardır. Çağlar boyunca döneminin teknolojik hızına ayak uyduramayan veya geç kalan uluslar yok olmuş veya yıkılmışlardır. Geniş bir çerçeveden bakılarak tiyatronun özüne de zarar vermeden çağının teknik ve teknolojik getirilerini tiyatro sanatına uygulamak zorundayız gibi gözükmektedir. "Eğer güncel teknolojiyle geleneksel sahne estetiği arasında bir köprü kurulamaz ise, tiyatro sanatı çağımızın görsel estetiği ile bağdaşamayan geleneksel yapısına saplanıp kalacak ve yoluna giderek zayıflayan ve estetik bütünlüğünü yitiren bir yapıyla devam edebilecektir" (Gergin, 2013, s. 34).

Yeni bir teknolojik unsur olan sanal gerçeklik teknolojisiyle birlikte çağımızın gereği olan teknoloji kullanımını en üst deneyime taşıyan bu teknolojik gelişme, geçmişten günümüze tiyatro sanatı özelinde sahne tasarımı eyleminin farklı boyut ve ufaklara yönlendirebileceği gözlenmektedir. Günümüzde var olan tartışmalar içerisinde belki de en başta geleni tiyatronun antik olana mitsel ve tinsel olana geri dönmesi gerektiği tartışmasıdır. Frederic Niche'den Peter Brook'a, tarihsel avangard akımlardan günümüz post modern tiyatro düşünürlerine birçoklarının ortak düşüncesi bu olmuştur. Kaçırılmaması gereken bir gerçek vardır. Araştırmamızda da görülmüştür ki geçmişten günümüze tiyatro sanatı içinde bulunmuş olduğu çağın teknik ve teknolojik gelişimlerinden kendine uygun olan ve işine yarayan yenilikleri bünyesine kabul etmiştir. İnsan algısı artık multimedya teknolojileri sosyal medya vb. yeniliklerden etkilenerek zaman ve mekânda olan deneyimlerimizin değiştiği gözlenmektedir. Bu değişim neticesinde tiyatro eyleminin sacayaklarından biri olan seyircisini kendine çekmesi zaruri bir ihtiyaç haline gelmiştir. Günümüz seyircisinin tiyatro yerine sinemayı tercih etmesi bunu gören büyük şirketlerin tiyatro yerine sinemaya yatırım yapmalarıyla birlikte seyirci kitlesi büyük oranda sinemaya kaymıştır. Hiç şüphesiz çağının seyircisini tiyatroya çekebilmek için teknik ve teknolojik yeniliklerden faydalanarak alternatif tiyatro denemeleri sunulmalıdır.

Özellikle tiyatro açısından gelişmiş ülkelerde tiyatro sanatının daha geniş ve farklı kitlelere ulaştırabilmek gündelik ve deneysel çalışmalarında teknolojiyi tiyatro özelinde sahne tasarımı eyleminde kullanıldığı gözlenmektedir. Çalışmamızda söz ettiğimiz 3D mapping yöntemi batı ve uzak doğuda gelişmiş olan toplumlarda kullanıldığı bilinmektedir. Ülkemizde de özellikle devlet tiyatro ve operasında 3D mapping teknolojisi kullanılarak yapılan işler gözlenmektedir. Yapılan bu işler dünya standartlarına göre biraz geri kalmaktadır. Özellikle teknolojiyi üreten ülkelerdeki teknolojiye ulaşma imkanıyla ülkemizde ulaşılabilme ihtimalinde büyük bir uçurum olduğunu bilinmektedir. Projeksiyon teknolojisinin örneklerini az da olsa gördüğümüz ülkemizde tiyatro özelinde sanal gerçekli ve artırılmış gerçeklikle ilgili yapılmış çalışmalara ulaşılamamaktadır. Özellikle günümüzde görülmüştür ki herhangi bir salgın (covid-19) hastalık durumunda tiyatro sanatının yaşatılabilmesi için alternatif gösterim mecralarına ihtiyaç vardır. Belki de bu ihtiyacı karşılayacak teknolojik unsur sanal gerçeklik ve artırılmış gerçeklik teknolojisi olacaktır.

Yapak zekâ teknolojisi ile modellenen birçok yazılım hayatımızın her alanına etki etmeye başlamıştır. Çalışmamızda söz ettiğimiz DALL-E programı tasarım alanında gözlenen yapay zekâ teknolojisinin en somut örneğidir. Sadece sözcükler sayesinde birçok alanda üretim gerçekleştirebilen yapay zekâ modeli DALL-E, sahne tasarımı alanında da belki bütün tasarım olmasa da gerekli birçok parçanın tasarımını hızla gerçekleştirmek konusunda bizlere yardımcı olabileceği gözlenmektedir. 


\section{Kaynakça}

Aksel, E. (1988). Tiyatro tasarımının iç yapısı, tasarımcının ödevleri. Mimar Sinan Üniversitesi Matbaası.

Alpar, S. (2006). Bauhaus'un sahne tasarımına etkileri (Tez No. 285982) [Yüksek Lisans Tezi, Dokuz Eylül Üniversitesi]. Yüksek Öğretim Kurulu Tez Merkezi.

Anadol, R. (2019). Machine hallucination [Dijital enstalasyon]. Refik Anadol Studio, Newyork, US. https://refikanadol.com/works/machine-hallucination/

Aydın, S. N. (2020, 22 Temmuz). Sanat tasarımında bir deha: Olafur Eliasson. Arkitekt, https://www.gzt.com/ arkitekt/sanat-tasariminda-bir-deha-olafur-eliasson-3548205

Aydoğdu, Ü. (1997). Meyerhold ve Piscator'un gerçekçi tiyatroya karşı bütüncül tiyatro anlayışları (Tez No. 61184) [Yüksek Lisans Tezi, Anadolu Üniversitesi]. Yüksek Öğretim Kurulu Tez Merkezi.

Bayraktar, E., \& Kaleli, F. (2007). Sanal gerçeklik ve uygulama alanları. M. Akgül, E. Derman, U. Çağlayan ve A. Özgit (Eds.), IX. akademik bilişim konferansı bildirileri kitabı (s. 315-321) içinde. Yenidoğan Cilt ve Kirtasiye. https://ab.org.tr/kitap/ab07.pdf

Brockett, O. G. (2000). Tiyatro tarihi. Dost Kitabevi Yayınları.

Bulut B. (2018, 06 Temmuz). Milano fermanı, Roma İmparatorluğu ve Hristiyanlar. Wannart. https://wannart.com/icerik/8789-milano-fermani-ve-roma-imparatorlugunun-hristiyanligi-kabulu

Candan, A. (2003). Yirminci yüzyılda öncü tiyatro (1. Basım). İstanbul Bilgi Üniversitesi Yayınları.

Craig, E. G. (t.y.). Moskova sanat tiyatrosu "Hamlet” sahne tasarımı [Fotoğraf]. Mazia Laddour. http://mazialaddour.blogspot.com/2011/05/edward-gordon-craig.html

Çalışlar, A. (1993). 20. yüzyılda tiyatro. Mitos Boyut Yayınları.

Çelenk, S. (2007). Bu Dünyadan bir scenograf geçti. YEDI Dokuz Eylül Üniversitesi Güzel Sanatlar Fakültesi Dergisi, 1, 8-13. https://dergipark.org.tr/tr/download/article-file/203651

Çevik, M. (2007). Çăgdaş Alman sahne tasarımcılarından Günther Schneider Siemssen'nin sahne tasarımına getirdiği boyutlar (Tez No. 219411) [Yüksek Lisans Tez, Dokuz Eylül Üniversitesi]. Yüksek Öğretim Kurulu Tez Merkezi.

Çevikayak, C. (2016). Sahne tasarımında çok yönlü bir isim: Es Devlin. SDÜ ART-E Güzel Sanatlar Fakültesi Sanat Dergisi, 9(18), 382-400. https://dergipark.org.tr/tr/download/article-file/263443

Dervişoğlu, E. (2008). Mekân ve beden ilişkisi: Mekânın bedenle kavrayış üzerinden değerlendirilmesi (Tez No. 251713) [Yüksek Lisans Tezi, İstanbul Teknik Üniversitesi]. Yüksek Öğretim Kurulu Tez Merkezi.

Dixon, S. (2007). Digital performance: A history of new media in theatre, dance, performance art and installation. MiT Press.

Eliasson, O. (2003). The Weather enstalasyonu [Enstalasyon]. Tate Modern Müzesi, Londra. https://www.gzt. com/arkitekt/sanat-tasariminda-bir-deha-olafur-eliasson-3548205

Eliasson, O. (2014). Inside the horizon enstalasyonu [Enstalasyon]. Louis Vuitton Vakf1, Paris. https://www.gzt. com/arkitekt/sanat-tasariminda-bir-deha-olafur-eliasson-3548205

Erbas, A. (2021, 07 Ocak). DALL-E metindeki açıklamaları görselleştiriyor. TRAI. https://turkiye.ai/dall-emetindeki-aciklamalari-gorsellestiriyor/

Es Devlin, E. (t.y.). Wire-flag:burning set tasarımı [Fotoğraf]. Esdevlin. https://esdevlin.com/work/wire

Gergin, A. (2013). Günümüz seyircisini etkilemede, tiyatral anlatım ve sinematografik anlatım olanaklarının farklı boyutlart üzerine bir model önerisi (Tez No. 346009) [Doktora Tezi, Dokuz Eylül Üniversitesi]. Yüksek Öğretim Kurulu Tez Merkezi.

Gropius, W. (t.y.). Piscator için hazırlanan total tiyatro çizimleri [Fotoğraf]. Pinterest. https://tr.pinterest.com/pin/ $\underline{484981453608270843 /}$

It's Nice That. (2015, 29 Temmuz). Here 2013: Es Devlin [Video]. YouTube. https://www.youtube.com/watch?v =nOo9TWaxPmU

iC3DsFX. (t.y.). Pepper's Ghost yöntemi [Fotoğraf]. iC3DsFX - The 3D Ideas Company. https://www.ic3dsfx.co. uk/peppers-ghost-overview 
İpşirlioğlu, Z. (2004). Yeni bir alımlama boyutu. Tiyatro Eleştirmenliği ve Dramaturji Bölümü Dergisi, 0(4), 6979. https://dergipark.org.tr/tr/download/article-file/172510

Kaleli, S. (2016, 15 Mayıs). Robert Wilson ile söyleşi gerçekleştirildi. Mimesis Haber. http://www.mimesisdergi.org/2016/05/robert-wilson-ile-soylesi-gerceklestirildi/

Lepage, R. (1991). İgne ve afyon (Needles and opium) [Fotoğraf]. Toronto Star. https://www.thestar.com/ entertainment/stage/2013/11/20/robert lepage revisits his old vices in needles and opium.html

Martin, D. (2002, 22 Nisan). Josef Svoboda, 81, stage designer for hundreds of productions. The NewYork Times. https://www.nytimes.com/2002/04/22/theater/josef-svoboda-81-stage-designer-for-hundreds-of-productions. $\underline{\mathrm{html}}$

Nutku, Ö. (1985). Dünya tiyatrosu tarihi (Cilt 2). Remzi Kitabevi.

OpenAI. (t.y.). DALL-E salyangoz resimleri [Fotoğraf]. Zhuanlan. https://zhuanlan.zhihu.com/p/342270957

Öymen, E. E. (2007, 22 Nisan). Sahnede teknolojik yenilik. BT haber Haftalık Bilgi Toplumu Teknolojileri Gazetesi, s. 616.

Özdemir, A. (2012). Bir sahne bileşeni olarak zenginleştirilmiş gerçekliğin tiyatro mekânında değerlendirilmesi (Tez No. 349653) [Yüksek Lisans Tezi, İstanbul Teknik Üniversitesi]. Yüksek Öğretim Kurulu Tez Merkezi.

Öztuna, Y. (2007). Grafik tasarım ve görsel iletişim. Kültürü Dergisi, 12, İstanbul.

Pahlen, K. (2001). Die bühne mein leben. Springer.

Plufke, J. (t.y.). Pepper's Ghost yöntemi [Fotoğraf]. The Mary Sue. https://www.themarysue.com/how-coachellatupac-hologram-worked/

Sabankaya, E. (2016). Bauhaus Okulu'nun heykel sanatı ve sahne tasarımına etkileri ve bir performans uygulaması (Tez No. 428204) [Yüksek Lisans Tezi, Atatürk Üniversitesi]. Yüksek Öğretim Kurulu Tez Merkezi.

Schneider Siemssen, G. (1995/96). Mystery-Musical von Georg Stampfer [Video]. Youtube. https://www.youtube. com/watch?v=D8id2uZXHrs

Steve Dixon. (2020, 12 Şubat). Wikipedia içinde. https://en.wikipedia.org/wiki/Steve Dixon_actor)

Svoboda, J. (t.y.). Diapolyekran ve Polyekran [Fotoğraf]. JosefSvoboda. http://www.svoboda-scenograph. cz/en/laterna-magika/

Şeyben, B. Y. 2016). Tiyatro ve multimedya. Habitus Yayıncılık.

The Woost Projects. (1982). Bizim şehir (Our town) [Fotoğraf]. The Wooster Group. http://www. thewoostergroup.org/ thewoost/projects/TTHA_Barbican/

TheaterVR. (t.y.). TheaterVR kalevala.episodes teaser [Video]. Vimeo. https://vimeo.com/331466758

Tirben, B. (2018). Tiyatro oyunlarında video art kullanımı (Tez No. 505630) [Yüksek Lisans Tezi, Kocaeli Üniversitesi]. Yüksek Öğretim Kurulu Tez Merkezi.

Tunalı, İ. (2006). Bir kültür kategorisi olarak avangard üstüne. Rh+Sanat Dergisi, 33. İstanbul.

Wilson, R. (2016). Garrincha operasından bir kare [Fotoğraf]. Robertwilson. http://www.robertwilson.com/ garrincha

Yıldırım, L., \& Sakalauskaite, J. (2011). Devrim sonrası ilk Sovyet modası'nın oluşturulmasına Popova ve Stepanova'nın konstrüktivist yaklaşımlarının etkisi. Yedi DEÜ GSF Dergisi, 6, 31-40. https://dergipark.org.tr/ $\underline{\operatorname{tr} / \text { download/article-file/203713 }}$

Yılmaz, Ç. (2019, 01 Aralık). Sahne tasarımı dünyasının tanrıçası Es Devlin. Yellowbos. https://yellowbos.com/sahne-tasarimi-es-devlin/

Yorgun, F. (2018). Antik Yunan tragedyalarında Tanrl ve kader kavramlarl (Tez No. 531388) [Yüksek Lisans Tezi, İnönü Üniversitesi]. Yüksek Öğretim Kurulu Tez Merkezi.

Zeren, M. A. (2017). Avangart ve Sovyet avangart sahne tasarımı (Tez No. 469783) [Yüksek Lisans Tezi, Dokuz Eylül Üniversitesi]. Yüksek Öğretim Kurulu Tez Merkezi. 